\title{
$1 \quad$ Altered gene expression and PTSD symptom dimensions in World Trade Center responders
}

3 Shelby Marchese ${ }^{1}$, Leo Cancelmo ${ }^{2}$, Olivia Diab ${ }^{2}$, Leah $\mathrm{Cahn}^{2}$, Cindy Aaronson ${ }^{2}$, Nikolaos P.

4 Daskalakis $^{2,3}$, Jamie Schaffer ${ }^{2}$, Sarah R Horn ${ }^{2}$, Jessica S. Johnson ${ }^{1}$, Clyde Schechter ${ }^{4}$, Frank Desarnaud ${ }^{2,5}$,

5 Linda M Bierer ${ }^{2,5}$, Iouri Makotkine ${ }^{2,5}$, Janine D Flory ${ }^{2,5}$, Michael Crane ${ }^{6}$, Jacqueline M. Moline ${ }^{7}$, Iris

6 G. Udasin ${ }^{8}$, Denise J. Harrison ${ }^{9}$, Panos Roussos ${ }^{1,2,10-12}$, Dennis S. Charney ${ }^{2,13,14}$, Karestan C Koenen ${ }^{15-}$

$7{ }^{17}$, Steven M. Southwick ${ }^{18-19}$, Rachel Yehuda ${ }^{2,5}$, Robert H. Pietrzak ${ }^{18-19}$, Laura M. Huckins ${ }^{1,2,10-}$

$8 \quad 12,20 *$, Adriana $\mathrm{Feder}^{2} *(*$ equal contribution $)$

9

$10{ }^{1}$ Pamela Sklar Division of Psychiatric Genomics, Icahn School of Medicine at Mount Sinai, New York,

11 NY 10029, USA

$12{ }^{2}$ Department of Psychiatry, Icahn School of Medicine at Mount Sinai, New York, NY 10029, USA

$13{ }^{3}$ Department of Psychiatry, McLean Hospital, Harvard Medical School, Belmont, Massachusetts, USA

$14{ }^{4}$ Department of Family and Social Medicine, Albert Einstein College of Medicine of Yeshiva

15 University, Bronx, NY, USA

$16{ }^{5}$ Department of Psychiatry, James J. Peters Veterans Affairs Medical Center, Bronx, New York, USA

$17{ }^{6}$ Department of Environmental Medicine and Public Health, Icahn School of Medicine at Mount Sinai,

18 New York, NY, USA

$19{ }^{7}$ Department of Occupational Medicine, Epidemiology and Prevention, Zucker School of Medicine at

20 Hofstra/Northwell, Great Neck, NY, USA

$21{ }^{8}$ Environmental and Occupational Health Sciences Institute, School of Public Health, Rutgers

22 University, Piscataway, NJ, USA

$23{ }^{9}$ Department of Medicine, Division of Pulmonary Critical Care and Sleep Medicine, NYU School of

24 Medicine, New York, NY, USA

$25{ }^{10}$ Department of Genetics and Genomic Sciences, Icahn School of Medicine at Mount Sinai, New York, 26 NY 10029, USA 
medRxiv preprint doi: https://doi.org/10.1101/2021.03.05.21252989; this version posted March 12, 2021. The copyright holder for this preprint (which was not certified by peer review) is the author/funder, who has granted medRxiv a license to display the preprint in perpetuity.

It is made available under a CC-BY-NC-ND 4.0 International license .

$27{ }^{11}$ Icahn Institute for Genomics and Multiscale Biology, Icahn School of Medicine at Mount Sinai, New

28 York, NY 10029, USA

$29{ }^{12}$ Mental Illness Research, Education and Clinical Centers, James J. Peters Department of Veterans

30 Affairs Medical Center, Bronx, NY 14068, USA

$31{ }^{13}$ Department of Neuroscience, Icahn School of Medicine at Mount Sinai, New York, New York, USA.

$32{ }^{14}$ Department of Pharmacological Sciences, Icahn School of Medicine at Mount Sinai, New York, New

33 York, USA.

$34{ }^{15}$ Massachusetts General Hospital, Psychiatric and Neurodevelopmental Genetics Unit (PNGU), Boston, 35 MA, USA.

$36{ }^{16}$ Broad Institute of MIT and Harvard, Stanley Center for Psychiatric Research, Cambridge, MA, USA.

$37{ }^{17}$ Harvard School of Public Health, Department of Epidemiology, Boston, MA, USA.

$38{ }^{18}$ Department of Psychiatry, Yale University School of Medicine, New Haven, CT, USA

$39{ }^{19}$ Department of Veterans Affairs National Center for Posttraumatic Stress Disorder, VA Connecticut

40 Healthcare System, West Haven, CT, USA

$41{ }^{20}$ Seaver Autism Center for Research and Treatment, Icahn School of Medicine at Mount Sinai, New

$42 \quad$ York, NY 10029, USA

43

44

45

46 
medRxiv preprint doi: https://doi.org/10.1101/2021.03.05.21252989; this version posted March 12, 2021. The copyright holder for this preprint (which was not certified by peer review) is the author/funder, who has granted medRxiv a license to display the preprint in perpetuity.

It is made available under a CC-BY-NC-ND 4.0 International license .

\section{Abstract}

Despite experiencing a significant trauma, only a subset of World Trade Center (WTC) rescue

50 and recovery workers developed posttraumatic stress disorder (PTSD). Identification of

51 biomarkers is critical to the development of targeted interventions for treating disaster responders

52 and potentially preventing the development of PTSD in this population. Analysis of gene

53 expression from these individuals can help in identifying biomarkers of PTSD.

55 We established a well-phenotyped sample of 371 WTC responders, recruited from a longitudinal

56 WTC responder cohort, by obtaining blood, self-reported and clinical interview data. Using bulk

57 RNA-sequencing from whole blood, we examined the association between gene expression and

58 WTC-related PTSD symptom severity on (i) highest lifetime Clinician-Administered PTSD

59 Scale (CAPS) score, (ii) past-month CAPS score, and (iii) PTSD symptom dimensions using a 5-

60 factor model of re-experiencing, avoidance, emotional numbing, dysphoric arousal and anxious

61 arousal symptoms. We corrected for sex, age, genotype-derived principal components and

62 surrogate variables. Finally, we performed a meta-analysis with existing PTSD studies (total

$63 \mathrm{~N}=1,016$ ), using case/control status as the predictor and correcting for these variables.

65 We identified 66 genes significantly associated with highest lifetime CAPS score (FDRcorrected $\mathrm{p}<0.05$ ), and 31 genes associated with past-month CAPS. Our more granular analyses

67 of PTSD symptom dimensions identified additional genes that did not reach statistical

68 significance in our overall analysis. In particular, we identified 82 genes significantly associated

69 with lifetime anxious arousal symptoms. Several genes significantly associated with multiple

70 PTSD symptom dimensions and lifetime CAPS score (SERPINA1, RPS6KA1, and STAT3) have 
medRxiv preprint doi: https://doi.org/10.1101/2021.03.05.21252989; this version posted March 12, 2021. The copyright holder for this preprint (which was not certified by peer review) is the author/funder, who has granted medRxiv a license to display the preprint in perpetuity.

It is made available under a CC-BY-NC-ND 4.0 International license .

71 been previously associated with PTSD. Geneset enrichment of these findings has identified

72 pathways significant in metabolism, immune signaling, other psychiatric disorders, neurological

73 signaling, and cellular structure. Our meta-analysis revealed 10 genes that reached genome-wide

74 significance, all of which were down-regulated in cases compared to controls (CIRBP, TMSB10,

75 FCGRT, CLIC1, RPS6KB2, HNRNPUL1, ALDOA, NACA, ZNF429 and COPE). Additionally,

76 cellular deconvolution highlighted an enrichment in CD4 T cells and eosinophils in responders

77 with PTSD compared to controls.

78

79 The distinction in significant genes between lifetime CAPS score and the anxious arousal

80 symptom dimension of PTSD highlights a potential biological difference in the mechanism

81 underlying the heterogeneity of the PTSD phenotype. Future studies should be clear about

82 methods used to analyze PTSD status, as phenotypes based on PTSD symptom dimensions may

83 yield different gene sets than combined CAPS score analysis. Potential biomarkers implicated

84 from our meta-analysis may help improve therapeutic target development for PTSD. 
medRxiv preprint doi: https://doi.org/10.1101/2021.03.05.21252989; this version posted March 12, 2021. The copyright holder for this preprint (which was not certified by peer review) is the author/funder, who has granted medRxiv a license to display the preprint in perpetuity.

It is made available under a CC-BY-NC-ND 4.0 International license .

\section{Introduction}

86 Posttraumatic stress disorder (PTSD) is a complex psychiatric disorder that can develop after

87 experiencing a traumatic event. The attacks on the World Trade Center (WTC) on September 11,

882001 and their aftermath had a substantial impact on the physical and mental health of WTC

89 rescue, recovery and clean-up workers, but only a subset developed PTSD. These differing

90 clinical outcomes after experiencing trauma imply a role for biological and genetic influence in

91 PTSD. Our cohort provides an unprecedented opportunity into PTSD insights, because they have

92 been deeply phenotyped for a shared, specific trauma.

94 Understanding the biological mechanisms underlying PTSD will require careful dissection and

95 analysis of many constituent symptoms and risk factors. PTSD is uniquely heterogeneous among

96 psychiatric disorders, with complex and detailed diagnostic criteria that allow for 636,120

97 different combinations of symptoms ${ }^{1}$, and 79,794 different symptom combinations. Additional

98 heterogeneity in PTSD stems from the type and extent of trauma. It has been well established

99 that PTSD is a heterogenous disorder and that trauma type plays a role in differential outcomes.

100 In the field of WTC exposures, some work has already been done to elucidate gene expression

101 and clinical outcomes. ${ }^{2-10}$ Further, work by our group and others has demonstrated differential

102 genetic heritability of PTSD according to trauma-type ${ }^{11,12}$.

103

104 Identification of biomarkers will be critical to the development of targeted interventions for

105 treating disaster responders and potentially preventing the development of PTSD in this

106 population. Gene expression analysis from WTC responders is uniquely useful to deduce the

107 biological heterogeneity in PTSD, given their exposure to a similar and well-documented trauma. 
medRxiv preprint doi: https://doi.org/10.1101/2021.03.05.21252989; this version posted March 12, 2021. The copyright holder for this preprint (which was not certified by peer review) is the author/funder, who has granted medRxiv a license to display the preprint in perpetuity.

It is made available under a CC-BY-NC-ND 4.0 International license .

108 Data on WTC-related traumatic exposures of responders analyzed here, in combination with

109 their heterogenic clinical outcomes, makes this a critical study to understand PTSD development

110 and chronicity after shared traumatic events. Although candidate gene expression and

111 methylation studies have explored genes involved in canonical stress signaling pathways in

112 PTSD, regulated by the hypothalamus-pituitary-adrenal (HPA) axis, and immune and

113 sympathetic nervous systems, few have been able to control for length of time since exposure,

114 nor so specifically delineate trauma type and secondary exposures such as dust cloud severity.

115 While the WTC-related exposures experienced by rescue, recovery and clean-up workers in this

116 cohort ranged in severity, the traumatic event -encompassing the 9/11 attacks and their

117 aftermath- happened in a discrete, specific time window. Further, this sample is highly

118 phenotyped with in-person clinical psychiatric evaluations, also including medical examination

119 and laboratory testing.

120

121 The existence of this cohort and the generous participation of many responders to the WTC

122 disaster enabled us to generate a large gene expression data set of 355 donors, to our knowledge

123 the largest single traumatic event expression data set to date. We used the Clinician-

124 Administered PTSD Scale (CAPS) ${ }^{13}$ score as a quantitative measure of PTSD symptom severity

125 rather than a case/control definition, thus substantially increasing statistical power in this

126 study. ${ }^{14-16}$ To our knowledge, ours is the first gene expression study to incorporate total CAPS

127 scores and PTSD symptom dimensions as outcomes. 


\section{Methods}

\section{Participants}

131 The WTC Health Program (WTC-HP) is a regional consortium of five clinical centers

132 established in the greater New York City area by the Centers of Disease Control and Prevention

133 in 2002, with the goal of providing health monitoring and treatment to WTC responders,

134 comprising the WTC-HP General Responder Cohort ${ }^{17}$. We recruited participants from the WTC-

135 HP Responder Cohort who had completed at least three periodic health monitoring visits at one

136 of the four WTC-HP clinical centers participating in this study - Mount Sinai Medical Center,

137 New York University, Northwell Health, and Rutgers/The State University of New Jersey - and

138 who had provided signed consent to be contacted for research studies. Stratified random

139 sampling was employed to ensure selection of WTC responders spanning the full range of WTC-

140 related PTSD symptom severity, from no/minimal symptoms to severe/chronic PTSD symptom

141 levels on the PTSD Checklist - Specific Version (PCL-S) ${ }^{18}$ completed during periodic health

142 monitoring visits to the WTC-HP. Individuals with a lifetime history of chronic psychotic

143 disorder or bipolar disorder type I, substance abuse/dependence or alcohol dependence over the

144 prior three months, current pregnancy, acute medical illness or exacerbation of chronic medical

145 illness, history of significant head injury or cerebrovascular accident, changes in medications or

146 medication dosages over the prior month, or who were taking oral or regularly injected steroid

147 medications were excluded from the study.

149 The study, conducted between April 2013 and September 2017, was approved by the

150 Institutional Review Board of the Icahn School of Medicine at Mount Sinai, and all participants

151 provided written informed consent. A total of 471 WTC responders completed in-person clinical 
medRxiv preprint doi: https://doi.org/10.1101/2021.03.05.21252989; this version posted March 12, 2021. The copyright holder for this preprint (which was not certified by peer review) is the author/funder, who has granted medRxiv a license to display the preprint in perpetuity.

It is made available under a CC-BY-NC-ND 4.0 International license .

152 assessments, yielding a final sample of 371 participants who met study eligibility criteria and

153 completed study procedures, and 355 of those who had viable RNA-sequencing data (Figure 1).

154 The mean age of participants was $54.1(\mathrm{SD}=8.3)$ years, $82 \%$ were male; ethnicity proportions are

155 given in Table 1. The sample was composed of $40.8 \%$ police responders and 59.2\% non-

156 traditional responders (e.g., construction workers).

158 Assessments

159 Data on 10 WTC-related exposures ${ }^{19}$ (e.g., exposed to human remains, received treatment for an

160 illness/injury during WTC recovery work) was obtained from interviews and self-report

161 questionnaires completed by participants during their first health-monitoring visit to the WTC-

$162 \mathrm{HP}$, an average of $4.3(\mathrm{SD}=2.7)$ years following 9/11/2001. In-person clinical assessments were

163 conducted an average of $13(\mathrm{SD}=2.3)$ years following 9/11/2011. Trained Masters- or PhD-level

164 clinical interviewers administered the Structured Clinical Interview for DSM-IV (SCID) ${ }^{1}$ to

165 assess current and lifetime Axis-I psychiatric diagnoses, and CAPS ${ }^{13}$, lifetime and past-month

166 versions, to assess lifetime and past-month WTC-related PTSD diagnostic status and WTC-

167 related PTSD symptom severity. Lifetime and past-month PTSD diagnosis was defined as

168 meeting DSM-IV criteria for WTC-related PTSD and a total score $\geq 40$ on the lifetime and past-

169 month CAPS, respectively.

170

171 On the same day as the clinical assessment, participants also completed the Childhood Trauma

172 Questionnaire $(\mathrm{CTQ})^{20}$, assessing physical, sexual, and emotional abuse, and physical and

173 emotional neglect experienced in childhood; the Traumatic Life Events Questionnaire (TLEQ) ${ }^{21}$,

174 assessing lifetime exposure to a range of traumatic events (e.g, crime, natural disaster, assault); a 
medRxiv preprint doi: https://doi.org/10.1101/2021.03.05.21252989; this version posted March 12, 2021. The copyright holder for this preprint (which was not certified by peer review) is the author/funder, who has granted medRxiv a license to display the preprint in perpetuity.

It is made available under a CC-BY-NC-ND 4.0 International license .

175 checklist of 15 stressful life events they might have experienced since 9/11/2011 (e.g., "lost a

176 job/laid off/lost income", "divorced from spouse", "had debt trouble"), modified from the

177 Diagnostic Interview Schedule (DIS) Disaster Supplement ${ }^{22}$; and a health questionnaire asking

178 which medical conditions they had ever been diagnosed with ${ }^{23}$, modified to add common WTC-

179 related conditions (asthma or chronic respiratory condition, chronic rhinitis or sinusitis, sleep

180 apnea, or acid reflux). Participants additionally completed a history and physical examination

181 conducted by a licensed nurse practitioner, as well as routine laboratory testing, to rule out acute

182 medical illness or exacerbation of chronic medical illness.

183

184 Among the 355 participants, 108 were determined to have met DSM-IV criteria for lifetime

185 WTC-related PTSD, with 53 of them still meeting past-month PTSD criteria. The heterogeneity

186 of PTSD confers some problems when attempting to analyze the disorder by case/control status

187 alone. Case/control analyses do not fully capture the symptom complexity of the disorder,

188 resulting in poor genomic modeling. Similarly, while overall PTSD symptom severity is a better

189 quantitative measurement, it does not fully capture variability across PTSD symptomatology on

190 a useful clinical level. ${ }^{24}$ To address this variability, we examined five symptom dimensions (re-

191 experiencing, avoidance, emotional numbing, dysphoric arousal and anxious arousal symptoms),

192 assessed with the CAPS to more accurately examine the heterogeneity of PTSD symptomatology

193 (Figure 2). ${ }^{25}$

194

\section{Blood sample collection and RNA extraction}

196 Participants were instructed to fast after midnight and underwent collection of blood samples

197 between 8:00 and 10:00 am. Total RNA was purified from whole blood collected in PAXgene 
medRxiv preprint doi: https://doi.org/10.1101/2021.03.05.21252989; this version posted March 12, 2021. The copyright holder for this preprint (which was not certified by peer review) is the author/funder, who has granted medRxiv a license to display the preprint in perpetuity.

It is made available under a CC-BY-NC-ND 4.0 International license .

199 (Qiagen, Germantown, MD, USA). Total RNA concentration and quality were estimated using a

200

201

202

203

204

205

206

207

208

209

210

\section{Gene expression quality control analysis}

212 We processed whole-blood gene expression data using the RAPiD.19 RNA-sequencing pipeline,

213 and calculated normalized TPM counts from $\mathrm{RSEM}^{26}$ We performed quality control analysis on

214 the counts to verify sequencing and residual contributions to variance using VariancePartition ${ }^{27}$.

215 We corrected each sequencing batch for sex, age, and genotype-derived principal components

216 using Limma/voom weighted least-squares linear regression. ${ }^{28}$ We rank normalized and

217 combined the residuals from the linear regression of each batch, and these values were used in all

218 subsequent association tests for CAPS total score and five PTSD dimension scores (re-

219 experiencing, avoidance, numbing, dysphoric arousal and anxious arousal). 
medRxiv preprint doi: https://doi.org/10.1101/2021.03.05.21252989; this version posted March 12, 2021. The copyright holder for this preprint (which was not certified by peer review) is the author/funder, who has granted medRxiv a license to display the preprint in perpetuity.

It is made available under a CC-BY-NC-ND 4.0 International license .

\section{Differential gene expression analysis}

222 We used whole blood RNA-sequencing to test for associations between gene expression and

223 WTC-related PTSD symptom severity on (i) highest lifetime CAPS score $\left(\mathrm{CAPS}_{\mathrm{L}}\right)$, (ii) past-

224 month CAPS score (CAPS PM , and (iii) PTSD dimension scores including re-experiencing,

225 avoidance, numbing, dysphoric arousal and anxious arousal, correcting for batch and surrogate

226 variables (Eqn. 1).

227

$$
\text { Gene expression } \sim D x+\text { batch }+ \text { surrogate variables }
$$

229 Equation 1. General equation for gene expression anaylsis.

231 In addition, study participants had a wide range of psychiatric and somatic comorbidities,

232 including some with substantial shared genetic aetiology and overlapping symptom profiles (e.g.,

233 major depressive disorder); comorbidities that may represent systemic manifestations of of

234 PTSD (e.g., cardiovascular disease ${ }^{29}$ ); and exposure to the dust cloud during and following 9/11.

235 We expect all of these factors to have substantial impacts on gene expression. Significant co-

236 linearity between some of these measures and CAPS scores preclude including these variables as

237 covariates within our analysis, and testing directly for their effect on gene expression (in

238 particular, due to high correlations between length of time at the WTC site, CAPS score, and

239 dust-cloud exposure [ref]; and between CAPS score and co-morbid medical disorders potentially

240 constituting systemic manifestations of PTSD). Instead, in order to test whether these

241 comorbidities and exposures might account for some of the CAPS-expression associations we

242 observe, we also tested for gene expression associations with (i) an index of dust cloud 
medRxiv preprint doi: https://doi.org/10.1101/2021.03.05.21252989; this version posted March 12, 2021. The copyright holder for this preprint (which was not certified by peer review) is the author/funder, who has granted medRxiv a license to display the preprint in perpetuity.

It is made available under a CC-BY-NC-ND 4.0 International license .

243 exposure ${ }^{30}$; and (ii) number of medical comorbidities. Next, we tested for (i) interaction effects

244 between each of these measures and CAPS score; (ii) enrichment of genome-wide significant

245 associations between these measures and CAPS score; and (iii) genome-wide correlations in

246 association statistics. For all gene expression analyses, we established significance using a

247 Benjamini-Hochberg ${ }^{31}$ FDR correction $<5 \%$.

248

249 Gene-set enrichment of PTSD-associated genes

250 We tested for gene set enrichment among our genes associated with $\mathrm{CAPS}_{\mathrm{L}}, \mathrm{CAPS}_{\mathrm{PM}}$, and PTSD

251 dimension scores by (i) analyzing the significant genes from the association tests for pathway

252 enrichment by gene permutation testing and (ii) analyzing all genes from the ranked association

253 test gene lists to subject permutation using the R versions of GSEA ${ }^{32}$ and fgsea $^{33,34}$. For gene

254 permutation testing, we included all nominally significant genes $(\mathrm{p}<0.05)$, and tested for

255 association with 105 gene sets using Kyoto Encyclopedia of Genes and Genomes (KEGG)

256 database $^{35}$ for pathway enrichment.

258 We applied phenotype permutation testing rather than gene set permutation to keep the

259 correlations between the genes in the dataset and the genes in the gene set pathways. For the

260 subject permutation testing, each test was run with 10000 permutations, and pathways that

261 passed Benjamini-Hochberg multiple testing correction were considered significantly enriched.

262 To synthesize this large amount of gene set information, we generated comparative PTSD

263 symptom plots using Clusterprofiler ${ }^{36}$ in R. Comparative gene set plots contained pathways

264 which passed FDR $<0.05$ significance threshold. 
medRxiv preprint doi: https://doi.org/10.1101/2021.03.05.21252989; this version posted March 12, 2021. The copyright holder for this preprint (which was not certified by peer review) is the author/funder, who has granted medRxiv a license to display the preprint in perpetuity.

It is made available under a CC-BY-NC-ND 4.0 International license .

Meta-analysis with existing gene expression analyses

267 To replicate our gene expression results, we meta-analyzed our data with association statistics

268 from five other genome-wide gene expression analyses:

1. WTC responder study Stony Brook University (SB WTC) ${ }^{3}$; N=282. Data are divided into discovery (WTC-d) and replication (WTC-r) cohorts.

272

2. Trauma Mega-Analysis study (TMA) ${ }^{12}$. TMA combines 7 different PTSD studies and transformed the expression data into three categories: combat $(\mathrm{N}=169)$, male interpersonal $(\mathrm{N}=112)$, and female interpersonal trauma $(\mathrm{N}=259)^{12}$. We analyzed these data as separate trauma studies for the purposes of our meta-analysis (Table 2).

Since the majority of studies focus on PTSD case/control status, rather than associations with

277 continuous CAPS scores (as here), we repeated our analysis to compare gene expression between

278 PTSD cases (defined as meeting DSM-IV criteria for PTSD and a total CAPS $\geq 40$ ) and controls

279 (all others in our sample).

281 We meta-analyzed PTSD case-control association statistics using a sample-size based meta282 analysis approach in METAL ${ }^{37}$. We included all genes from our analysis that reached $\mathrm{p}<0.05$

$283(\mathrm{~N}=9,380$ for past-month and $\mathrm{N}=1,016$ for lifetime) and all available genes from other studies $284 \quad(\mathrm{~N}=27-806 ;$ Table 2).

\section{Cellular deconvolution associated with CAPS scores}

288 patients using the immune cell matrix reference panel LM22 $2^{38}$. We tested for association

289 between cell type proportions and $\mathrm{CAPS}_{\mathrm{PM}}, \mathrm{CAPS}_{\mathrm{L}}$. 
medRxiv preprint doi: https://doi.org/10.1101/2021.03.05.21252989; this version posted March 12, 2021. The copyright holder for this preprint (which was not certified by peer review) is the author/funder, who has granted medRxiv a license to display the preprint in perpetuity.

It is made available under a CC-BY-NC-ND 4.0 International license .

\section{Results}

291 Gene expression is associated with PTSD symptom levels in WTC first responders

292 We tested for association between expression of 12,220 genes and total CAPS score in a sample

293 of 355 WTC first responders. We identified 31 genes significantly associated with total past-

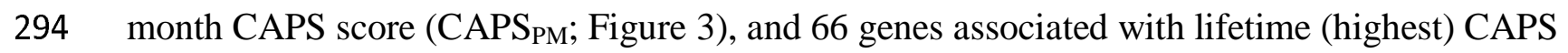

295 score $\left(\mathrm{CAPS}_{\mathrm{L}}\right.$, Figure 3). Of these, 42/66 genes are associated only with $\mathrm{CAPS}_{\mathrm{L}}$, (and not

296 CAPS $_{\mathrm{PM}}$ ), while 7/31 genes were associated only with CAPS ${ }_{\mathrm{PM}}$, (and not $\mathrm{CAPS}_{\mathrm{L}}$ ). Genome-wide

297 associations with $\mathrm{CAPS}_{\mathrm{PM}}$ and $\mathrm{CAPS}_{\mathrm{L}}$ were significantly correlated (Beta $\rho=0.82, \mathrm{p}<2.2 \times 10^{-16}$;

298 FDR-adjusted P-values $\rho=0.79, \mathrm{p}<2.2 \times 10^{-16}$ ) (Table 3).

300 We tested for enrichment of 59 well-studied PTSD candidate genes ${ }^{11}$ (Sup. Table 1) within our 301 association statistics. We did not observe enrichment of these genes within our past-month or

302 lifetime association analyses $(\mathrm{p}=0.174,0.245)$. However, of these candidate genes, SERPINAI

303 was significantly associated with $\mathrm{CAPS}_{\mathrm{L}}$ score.

304

\section{Environmental exposure to the WTC dust cloud}

306 Next, we tested whether our genes associated with CAPS scores are specific to PTSD, or are

307 driven by spurious associations with comorbid diagnoses or environmental exposure to the dust

308 cloud at Ground Zero. In particular, a number of individuals within our study have comorbid

309 conditions and complex medical histories (Table 4), including disorders with substantial shared

310 genetic and environmental etiology with PTSD, and disorders and traits that may present as

311 systemic manifestations of PTSD. 
medRxiv preprint doi: https://doi.org/10.1101/2021.03.05.21252989; this version posted March 12, 2021. The copyright holder for this preprint (which was not certified by peer review) is the author/funder, who has granted medRxiv a license to display the preprint in perpetuity.

It is made available under a CC-BY-NC-ND 4.0 International license .

313 First, we tested whether these medical comorbidities alone may account for the associations we

314 observe; we identified 175 gene associations with an aggregate summary score of medical

315 comorbidities. Notably, these genes do not include any of our significant associations with CAPS

316 scores. We identified only one gene, STX10, with significant interaction between CAPS scores

317 and comorbid conditions; that is, gene expression was elevated specifically among individuals

318 with both high $\mathrm{CAPS}_{\mathrm{L}}$ and a large number of comorbid diagnoses (Figure 4).

320 Next, we tested for association between gene expression and exposure to the dust cloud at

321 Ground Zero ${ }^{30}$. We identified 561 genes significantly associated with this exposure. We tested

322 for, but did not find, any significant interactions between CAPS scores and dust cloud exposure

$323(\mathrm{p}>0.05)$, and did not observe a large correlation of expression results in genome-wide

324 significant genes between the two analyses for $\mathrm{CAPS}_{\mathrm{PM}}$ or $\mathrm{CAPS}_{\mathrm{L}}\left(\mathrm{R}^{2}=0.1835, \mathrm{R}^{2}=0.2466\right.$,

$325 \mathrm{p}<0.05)$ (Figure 4). Together, these analyses imply that our gene-CAPS score associations are

326 specific and relevant to PTSD, rather than due to confounding by comorbid diagnoses or dust

327 cloud exposure.

328

329 Gene expression analysis reveals PTSD dimension-specific associations

330 Next, we tested for gene expression associations with past-month and lifetime PTSD symptom

331 dimensions (re-experiencing, avoidance, dysphoric arousal, anxious arousal, numbing; Sup.

332 Table 2).

333 Our analysis revealed overlapping and unique genes for each symptom dimension, and

334 significant correlation of genome-wide association statistics between symptom dimensions. 
medRxiv preprint doi: https://doi.org/10.1101/2021.03.05.21252989; this version posted March 12, 2021. The copyright holder for this preprint (which was not certified by peer review) is the author/funder, who has granted medRxiv a license to display the preprint in perpetuity.

It is made available under a CC-BY-NC-ND 4.0 International license .

335 In particular, both our past-month and lifetime analyses identified a large number of genes (61

336 and 82, respectively; Sup. Table 2) associated with anxious arousal, including many genes not

337 associated with any other phenotype in our analysis (16, 27, respectively). By contrast, although

338 we identified a substantial number of genes significantly associated with dysphoric arousal (20,

33916 for past-month and lifetime respectively), only two genes were uniquely associated with this

340 phenotype (1 gene in past-month; 2 in lifetime). Only one gene, COPE, was significantly

341 associated with every phenotype tested in our analysis. A second gene, EIF4A1, was also

342 significantly associated with every lifetime (highest) phenotype (Figure 5).

344 PTSD pathway enrichment demonstrates immune, psychiatric, and metabolic relationships

345 Our genetic enrichment and pathway analyses identified well-established PTSD mechanisms and

346 pathways, including pathways associated with inflammation, neurological signaling pathways,

347 structural remodeling within and between cells, and HPA-axis and signaling ${ }^{39-44}$. Based on our

348 KEGG pathway enrichment analysis, we revealed a set of genes significantly associated with

349 psychiatric disorders pathways that were significantly enriched in our results: FURIN, PPP2RIA,

350 GNAI2, PCLB2, and GNB2. The two symptoms that we discovered were associated with FURIN

351 and their FDR-corrected $p$-values were avoidance $(p=0.028, B=2.55)$ and numbing $(p=0.034$,

$352 \mathrm{~B}=-0.009) . P P P 2 R 1 A$ was associated with anxious arousal ( $\mathrm{p}=0.009, \mathrm{~B}=2.60) . P C L B 2$ was only

353 associated with numbing $(\mathrm{p}=0.046, \mathrm{~B}=-0.952)$. GNAI2 was associated with anxious arousal

$354(\mathrm{p}=0.042, \mathrm{~B}=-0.780)$ and numbing $(\mathrm{p}=0.047, \mathrm{~B}=-1.03)$, and $G N B 2$ was only associated with

355 avoidance $(\mathrm{p}=0.036, \mathrm{~B}=1.130)$ (Figure 6). 
medRxiv preprint doi: https://doi.org/10.1101/2021.03.05.21252989; this version posted March 12, 2021. The copyright holder for this preprint (which was not certified by peer review) is the author/funder, who has granted medRxiv a license to display the preprint in perpetuity.

It is made available under a CC-BY-NC-ND 4.0 International license .

357 Immunological and metabolic gene enrichment was consistent across $\mathrm{CAPS}_{\mathrm{L}}$ score and numbing,

358 but was less pronounced in anxious arousal. For past-month analyses, immune function was most

359 associated with anxious arousal, whereas metabolic function was enriched in $\mathrm{CAPS}_{\mathrm{PM}}$, and

360 numbing, to a lesser extent. For both lifetime and past-month scores, neurological signaling

361 pathways were most significantly pronounced in numbing, and were less prevalent in the overall

362 total CAPS score analysis. For lifetime scores, structural pathway enrichment was significantly

363 higher in total CAPS score, anxious arousal, and numbing, whereas for past-month scores,

364 structural enrichment was most associated with anxious arousal (Figure 6).

365

366 Meta-analysis prioritizes 10 genes associated with PTSD

367 We sought to replicate our associations with previous PTSD studies. Since the majority of

368 publicly available PTSD gene expression analyses follow a case-control, rather than quantitative

369 measure (CAPS score) analysis, we converted our continuous CAPS $_{\mathrm{PM}}$ and $\mathrm{CAPS}_{\mathrm{L}}$ values to

370 PTSD case/control using (CAPS $\geq$ 40) and DSM-IV PTSD-criteria, and repeated our analysis.

371 Our case/control and CAPS score association statistics were significantly correlated $(\rho=0.72$,

$\left.372 \mathrm{p}<2.2 \times 10^{-16}, \rho=0.79, \mathrm{p}<2.2 \times 10^{-16}\right)$; however, we note a substantial decrease in the number of

373 significantly associated genes when using a case-control design, compared to our initial

374 quantitative analysis, as we would expect ${ }^{16}$. Twelve genes were significant for past-month PTSD

$375\left(\mathrm{PTSD}_{\mathrm{PM}}\right)$ case/control and 22 genes were significant for lifetime PTSD (PTSD $\left.\mathrm{L}\right)$ case/control,

376 versus 31 genes for $\mathrm{CAPS}_{\mathrm{PM}}$ and 66 genes for $\mathrm{CAPS}_{\mathrm{L}}$.

377

378 We meta-analyzed our results with five publicly available cohorts ( $N=739$ cases, 438 controls);

379 two including WTC responders, and three including combat and interpersonal trauma (Table 2). 
medRxiv preprint doi: https://doi.org/10.1101/2021.03.05.21252989; this version posted March 12, 2021. The copyright holder for this preprint (which was not certified by peer review) is the author/funder, who has granted medRxiv a license to display the preprint in perpetuity.

It is made available under a CC-BY-NC-ND 4.0 International license .

For PTSD $\mathrm{PM}_{\mathrm{P}}$ we identified 5 significant genes -COPE, CIRBP, FCGRT, NACA, and ZNF429

$\left(\mathrm{p}<5.33 \times 10^{-6}\right)$, and for PTSD $_{\mathrm{L}} 8$ significant genes -COPE, CIRBP, TMSB10, FCGRT, CLIC1,

382

RPS6KB2, HNRNPUL1 and ALDOA ( $\left.<44.92 \times 10^{-5}\right)$-, including genes associated with

383 inflammation and immune response (Figure 7). Of these 10 genes, only one (COPE) had

384 significant heterogeneity of effect size between cohorts: our study and TMA-combat. Three

385 further genes were unique to our study; NACA $\mathrm{p}=3.34 \times 10^{-6}, C L I C 1, \mathrm{p}=1.9 \times 10^{-5}$, and HNRNPUL1

$386 \mathrm{p}=4.08 \times 10^{-5}$ (Figure 7). The remaining six genes were significant across multiple studies in our

387 meta-analysis, with highly consistent (negative) direction of effect (i.e., consistently decreased

388 expression in cases compared to controls): $Z N F 439\left(\mathrm{p}=4.78 \times 10^{-6}\right), C I R B P\left(\mathrm{p}=1.29 \times 10^{-6}\right)$,

$\operatorname{TMSB10}\left(\mathrm{p}=6.31 \times 10^{-6}\right), F C G R T\left(\mathrm{p}=1.12 \times 10^{-5}\right), \operatorname{RPS} 6 K B 2\left(\mathrm{p}=3.47 \times 10^{-5}\right)$, and ALDOA $(\mathrm{p}=4.66$

$\left.390 \times 10^{-5}\right)($ Table 5).

391

392 Cellular deconvolution identifies differences in cell populations between responders with

393 PTSD and controls

394 Since many of our PTSD-associated genes are related to immune function, we tested whether

395 immune cell type proportions were correlated with CAPS scores in individuals in our sample.

396 We performed cell-type deconvolution to identify cell-type proportions for 22 cell types across

397 all 355 individuals in our sample. We found significant increase of CD4 naïve T cell $(\mathrm{p}<0.0049)$

398 proportions with $\mathrm{CAPS}_{\mathrm{PM}}$, and significant increase of eosinophils $(\mathrm{p}<0.042)$ and CD4 memory

399 resting T cells $(\mathrm{p}<0.044)$ associated with $\mathrm{CAPS}_{\mathrm{L}}$. In addition, we found significant decrease of

400 activated natural killer cells $(\mathrm{p}<0.040)$ associated with $\mathrm{CAPS}_{\mathrm{L}}$. (Figure 8).

401 
medRxiv preprint doi: https://doi.org/10.1101/2021.03.05.21252989; this version posted March 12, 2021. The copyright holder for this preprint (which was not certified by peer review) is the author/funder, who has granted medRxiv a license to display the preprint in perpetuity.

It is made available under a CC-BY-NC-ND 4.0 International license .

402

403

404

405

406

407

408

409

410

411

412

413

414

415

416

417

418

419

420

421 Examining both lifetime and past-month CAPS scores allowed us to look at not only chronic

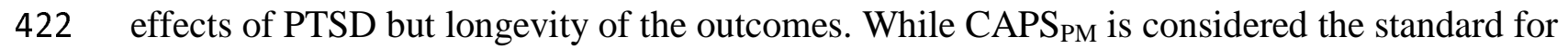

423 case/control analysis, looking at both $\mathrm{CAPS}_{\mathrm{L}}$ and $\mathrm{CAPS}_{\mathrm{PM}}$ allows us to ask more specific

424 questions about the role and relevance of elevated gene expression in PTSD. For example, genes 
medRxiv preprint doi: https://doi.org/10.1101/2021.03.05.21252989; this version posted March 12, 2021. The copyright holder for this preprint (which was not certified by peer review) is the author/funder, who has granted medRxiv a license to display the preprint in perpetuity.

It is made available under a CC-BY-NC-ND 4.0 International license .

425 associated with CAPS $_{\mathrm{PM}}$ might represent current expression changes in PTSD, while those

426 associated with $\mathrm{CAPS}_{\mathrm{L}}$ (lifetime CAPS score representing, for each responder, the highest WTC-

427 related PTSD symptom levels ever reached since 9/11/2011) may represent long-lasting

428 expression changes resulting from lifetime PTSD.

429

430 We identified genes associated with past-month and lifetime CAPS scores that have been

431 associated with other psychiatric disorders, such as major depressive disorder, schizophrenia and

432 autism: FURIN, PPP2RIA, PLCB2, GNAI2, and GNB2 (Figure 6) ${ }^{45-57}$. We additionally

433 identified a group of genes as significantly associated with several lifetime and past-month

434 PTSD symptom dimensions (SERPINA1, RPS6KA1, and STAT3) that have been previously

435 linked to PTSD pathophysiology $y^{1,27-31}$, and genes associated specifically with anxious arousal

436 that have been previously associated with anxiety disorders: $D C T N 1$, and $F L I 1^{58,59}$. One gene in

437 our study, COPE, was associated with every PTSD phenotype in this analysis. Until now, COPE

438 has not been well studied in the context of psychiatric disorders ${ }^{60}$, but it has been implicated in

439 the context of Alzheimer's disease ${ }^{61,62}$. Canonically, the COPE protein is the epsilon subunit of

440 the coatomer protein complex I (COPI) which regulates endocytosis from the plasma membrane

441 and is involved in Golgi-to-lysosome transportation. Other subunits of COPI have been

442 implicated in hereditary diseases that cause microcephaly and in autoimmune disorders ${ }^{63-65}$.

443

444 Importantly, our analytical design allowed us to test for potential confounding effects of

445 comorbidities and environmental exposures ${ }^{66,67}$. We expected many of these comorbidities and

446 exposures to have a significant impact on gene expression, particularly as some comorbidities

447 may be more recently occurring than, for example, the highest $\mathrm{CAPS}_{\mathrm{L}}$ measure. Therefore, we 
medRxiv preprint doi: https://doi.org/10.1101/2021.03.05.21252989; this version posted March 12, 2021. The copyright holder for this preprint (which was not certified by peer review) is the author/funder, who has granted medRxiv a license to display the preprint in perpetuity.

It is made available under a CC-BY-NC-ND 4.0 International license .

448 tested directly for genes associated with (i) comorbidities and (ii) dust cloud exposure. Although

449 we identified a large number of genes associated with each phenotype, we note that our

450 associations do not overlap with our top PTSD genes; we did not observe significant enrichment

451 of shared associations, and only observed one gene with significant interaction effect between

452 comorbidities and $\mathrm{CAPS}_{\mathrm{L}}$. Therefore, we conclude that our results are not confounded by these

453 exposures; our gene associations are specific to PTSD rather than broadly corresponding to

454 exposure or general ill-health.

455

456 KEGG enrichment of our associated genes determined genetic changes in metabolic,

457 immunological, structural, and neurological pathways associated with total CAPS, numbing, and

458 anxious arousal phenotypes (Figure 7). Anxious arousal and numbing tend to have few

459 significantly associated genes in common, while both past-month and lifetime CAPS scores

460 display a few unique genes but many shared ones. GNAI2, while associated with many numbing-

461 related pathways (long-term depression, oxytocin signaling, etc.), is also significantly associated

462 with some peripheral anxious arousal-related and $\mathrm{CAPS}_{\mathrm{L}}$-related pathways (leukocyte migration,

463 and chemokine signaling, respectively). On the other hand, anxious arousal is uniquely

464 associated with genes such as $H G S, A R F G A P 2$ and $R A B 7 A$, which are linked to endocytosis and

465 immunity. Similarly, our past-month and lifetime CAPS phenotypes are uniquely associated with

466 glycolysis/gluconeogenesis for genes $A L D O A, G A P D H, E N O 1, T P I 1$, and $P K M$, which may play

467 roles in HPA-axis or metabolic dysregulation (Table 4).

468

469 Our analyses identified 10 genes reaching genome-wide significance. Of these, 3/10 (NACA

$470 \mathrm{p}=3.34 \times 10^{-6}, C L I C 1, \mathrm{p}=1.9 \times 10^{-5}$, and HNRNPUL1 $\mathrm{p}=4.08 \times 10^{-5}$ ) are specific to our study; all 
471 three are downregulated in WTC responders with PTSD compared to controls. NACA has been

472 previously studied as a potential biomarker for depression in mice under stress conditions ${ }^{68}$. The

473 function of HNRNPUL1 is relatively unknown. Studies have suggested it might play a role in

474 DNA damage repair and nucleocytoplasmic RNA transport. CLIC1 has been implicated in other

475 psychiatric disorders, but its primary function is inflammasome regulation ${ }^{69-71}$. In addition, 6/10

476 genes had highly consistent directions of effect. These include $F C G R T\left(\mathrm{p}=1.12 \mathrm{x}^{-05}\right)$, which has

477 been characterized as an immune regulator of dendritic cell cross-presentation of IgG immune

478 complexes, necessary to activate a cytotoxic T-cell response and clear antigens ${ }^{72}$. Our analysis

479 demonstrates a down-regulation of FCGRT in WTC responders with PTSD, suggesting reduced

480 IgG immune complex clearance in these patients (Figure 6).

481

482 There is evidence that macro- and micro-level physiological damage is a fundamental component

483 of PTSD, as well as cytoskeletal restructuring for fear-based memory formation in the

484 amygdala ${ }^{43,44}$. In this study we observed decreased expression in $\operatorname{CIRBP}\left(\mathrm{p}=1.29 \mathrm{x}^{-06}\right)$, a protein

485 that traditionally regulates stress and apoptosis under conditions of extreme cold (Figure 6). Its

486 role as a potential biomarker has been previously explored for different psychiatric disorders ${ }^{73,74}$.

487 The decrease observed in TMSB10 expression also contributes to the dysregulation of apoptosis.

$488 T M S B 10$ is a pro-apoptotic protein that has been previously associated with downregulation of

489 gene expression after trauma exposure ${ }^{3,75,76}$. In our meta-analysis, the directionality of effect

$490\left(\mathrm{p}<2.2 \mathrm{x}^{-16}\right)$ for each gene was decreased, consistent with PTSD pathophysiology ${ }^{77,78}$.

491

492 Since many of our PTSD-associated genes are related to immune function, we tested for the

493 enrichment of immune cell types in our study. We found an overall enrichment of CD4-positive 
medRxiv preprint doi: https://doi.org/10.1101/2021.03.05.21252989; this version posted March 12, 2021. The copyright holder for this preprint (which was not certified by peer review) is the author/funder, who has granted medRxiv a license to display the preprint in perpetuity.

It is made available under a CC-BY-NC-ND 4.0 International license .

494 T cells for both past-month and lifetime CAPS scores (Figure 7), consistent with previous

495 studies $^{79,80}$, including among WTC responders ${ }^{8}$. In addition to CD4 T cell enrichment, our study

496 also found enrichment in eosinophils and a decrease in natural killer cells for CAPS $_{\mathrm{L}}$ (Figure 7).

497 These cellular diversities may point to a higher inflammatory signature in PTSD, particularly in

498 the case of CD4 T cell enrichment. It has been well demonstrated that dysregulation of CD4 T

499 cells leads to autoimmune activation ${ }^{81}$, and in combination with an increase in eosinophils can

500 lead to an inflammatory cascade in patients. There is strong evidence that PTSD is associated

501 with a pro-inflammatory state, which our findings support ${ }^{82-86}$.

502

503 While our study provides an in-depth look at the genetic expression and outcomes related to a

504 specific traumatic experience, we note some significant caveats. Our expression analysis was

505 limited to blood, but should be expanded to other tissues in the future, such as the brain.

506 Similarly, our analysis was restricted to whole blood, but a more in-depth single cell analysis

507 will be critical to determine gene expression in individual cell types. In addition, we note that our

508 cohort includes a significant proportion of individuals who have self-selected into high-risk

509 professions. As such, we expect a higher lifetime exposure to stressful situations, including

510 potentially many other life-threatening scenarios. It is likely that the PTSD symptoms observed

511 here are at least partially accounted for by other traumas and stressors, even though upon CAPS

512 administration, study clinicians specifically inquired about WTC-related PTSD symptoms.

513 Conversely, the high-risk nature of these individuals' occupations may also mean increased

514 exposure to resilience training for a sizable subsample, and greater access to social support

515 networks of peers with similar experiences, potentially providing protective mechanisms. 
medRxiv preprint doi: https://doi.org/10.1101/2021.03.05.21252989; this version posted March 12, 2021. The copyright holder for this preprint (which was not certified by peer review) is the author/funder, who has granted medRxiv a license to display the preprint in perpetuity.

It is made available under a CC-BY-NC-ND 4.0 International license.

517 In conclusion, this study has identified a vast number of biomarkers that will be potentially

518 useful tools after independent validation. In particular, ten of these genes stand out as

519 reproducible across multiple studies and should be considered as high priority. In combination

520 with pathway and cellular deconvolution results, these findings highlight a strong connection

521 with immune dysregulation and other psychiatric illnesses. We believe that future studies should

522 focus on validation of our PTSD-associated genes and also single-cell RNA-sequencing

523 approaches to delineate the role of immune cell types in PTSD. 
medRxiv preprint doi: https://doi.org/10.1101/2021.03.05.21252989; this version posted March 12, 2021. The copyright holder for this preprint (which was not certified by peer review) is the author/funder, who has granted medRxiv a license to display the preprint in perpetuity.

It is made available under a CC-BY-NC-ND 4.0 International license .

\section{References}

525 1. Spitzer RL, Gibbon M, Williams JBW. Structured Clinical Interview for DSM-IV Axis I

526 Disorders (SCID). N. Y. State Psychiatr. Inst. Biom. Res. N. Y. (1995).

527 2. Yehuda, R. et al. Gene Expression Patterns Associated with Posttraumatic Stress Disorder

528 Following Exposure to the World Trade Center Attacks. Biol. Psychiatry 66, 708-711 (2009).

529 3. Kuan, P.-F. et al. Gene expression associated with PTSD in World Trade Center responders:

$530 \quad$ An RNA sequencing study. Transl. Psychiatry 7, 1297 (2017).

531 4. Clouston, S. et al. Traumatic exposures, posttraumatic stress disorder, and cognitive

532 functioning in World Trade Center responders. Alzheimers Dement. N. Y. N 3, 593-602

533 (2017).

534 5. Clouston, S. A. P. et al. Posttraumatic stress disorder and total amyloid burden and amyloid-

$535 \quad \beta$ 42/40 ratios in plasma: Results from a pilot study of World Trade Center responders.

536 Alzheimers Dement. Amst. Neth. 11, 216-220 (2019).

537 6. Clouston, S. A. P. et al. Incidence of mild cognitive impairment in World Trade Center

538 responders: Long-term consequences of re-experiencing the events on 9/11/2001.

539 Alzheimers Dement. Diagn. Assess. Dis. Monit. 11, 628-636 (2019).

540 7. Gong, Y. et al. Prostate Cancer in World Trade Center Responders Demonstrates Evidence

541 of an Inflammatory Cascade. Mol. Cancer Res. 17, 1605-1612 (2019).

542 8. Kuan, P.-F. et al. Cell type-specific gene expression patterns associated with posttraumatic

543 stress disorder in World Trade Center responders. Transl. Psychiatry 9, 1-11 (2019).

544 9. Kuan, P.-F. et al. Enhanced exposure assessment and genome-wide DNA methylation in

$545 \quad$ World Trade Center disaster responders. Eur. J. Cancer Prev. 28, 225-233 (2019). 
medRxiv preprint doi: https://doi.org/10.1101/2021.03.05.21252989; this version posted March 12, 2021. The copyright holder for this preprint (which was not certified by peer review) is the author/funder, who has granted medRxiv a license to display the preprint in perpetuity. It is made available under a CC-BY-NC-ND 4.0 International license .

546 10. Sarapas, C. et al. Genetic Markers for PTSD Risk and Resilience Among Survivors of the

$547 \quad$ World Trade Center Attacks. Dis. Markers 30, 101-110 (2011).

548 11. Huckins, L. M. et al. Analysis of Genetically Regulated Gene Expression identifies a trauma

549 type specific PTSD gene, SNRNP35. bioRxiv 581124 (2019) doi:10.1101/581124.

550 12. Breen, M. S. et al. PTSD Blood Transcriptome Mega-Analysis: Shared Inflammatory

551 Pathways across Biological Sex and Modes of Trauma. Neuropsychopharmacology 43, 469-

$552481(2018)$.

553 13. Blake DD, Weathers FW, Nagy LM, et al. The development of a Clinician-Administered PTSD

554 Scale. J Trauma Stress 8(1), 75-90 (1995).

555 14. Fanous, A. H. \& Kendler, K. S. Genetic heterogeneity, modifier genes, and quantitative

556 phenotypes in psychiatric illness: searching for a framework. Mol. Psychiatry 10, 6-13

557 (2005).

558 15. Schijven, D. et al. Multivariate genome-wide analysis of stress-related quantitative

559 phenotypes. Eur. Neuropsychopharmacol. J. Eur. Coll. Neuropsychopharmacol. 29, 1354-

5601364 (2019).

561 16. Lee, S. H. \& Wray, N. R. Novel Genetic Analysis for Case-Control Genome-Wide Association

562 Studies: Quantification of Power and Genomic Prediction Accuracy. PLoS ONE 8, (2013).

563 17. Dasaro, C. R. et al. Cohort Profile: World Trade Center Health Program General Responder

564 Cohort. Int. J. Epidemiol. 46, e9 (2017).

565 18. Ruggiero, K. J., Del Ben, K., Scotti, J. R. \& Rabalais, A. E. Psychometric properties of the PTSD

566 Checklist-Civilian Version. J. Trauma. Stress 16, 495-502 (2003). 
medRxiv preprint doi: https://doi.org/10.1101/2021.03.05.21252989; this version posted March 12, 2021. The copyright holder for this preprint (which was not certified by peer review) is the author/funder, who has granted medRxiv a license to display the preprint in perpetuity.

It is made available under a CC-BY-NC-ND 4.0 International license .

567 19. Huckins, L. M. et al. Polygenic regulation of PTSD severity and outcomes among World

$568 \quad$ Trade Center responders. medRxiv 2020.12.06.20244772 (2020)

569 doi:10.1101/2020.12.06.20244772.

570 20. Bernstein, D. P. et al. Development and validation of a brief screening version of the

571 Childhood Trauma Questionnaire. Child Abuse Negl. 27, 169-190 (2003).

572 21. Kubany, E. S. et al. Development and preliminary validation of a brief broad-spectrum

573 measure of trauma exposure: the Traumatic Life Events Questionnaire. Psychol. Assess. 12,

$574 \quad 210-224(2000)$.

575 22. North, CS., et al. The Diagnostic Interview Schedule/Disaster Supplement (DIS-IV/DS). St

$576 \quad$ Louis Wash. Univ. (2001).

577 23. Pietrzak, R. H., Goldstein, R. B., Southwick, S. M. \& Grant, B. F. Medical comorbidity of full

578 and partial posttraumatic stress disorder in US adults: results from Wave 2 of the National

579 Epidemiologic Survey on Alcohol and Related Conditions. Psychosom. Med. 73, 697-707

$580 \quad$ (2011).

581 24. Horn, S. R. et al. Latent typologies of posttraumatic stress disorder in World Trade Center

582 responders. J. Psychiatr. Res. 83, 151-159 (2016).

583 25. Pietrzak, R. H., Tsai, J., Harpaz-Rotem, I., Whealin, J. M. \& Southwick, S. M. Support for a

584 novel five-factor model of posttraumatic stress symptoms in three independent samples of

585 Iraq/Afghanistan veterans: a confirmatory factor analytic study. J. Psychiatr. Res. 46, 317-

$586 \quad 322(2012)$.

587 26. Shah, H., Wang, Y.-C., Castellanos, R., Pandya, C., \& Giles, Z. RAPiD - An Agile and

588 Dependable RNA-Seq Framework. ASHG 2015 (2015). 
medRxiv preprint doi: https://doi.org/10.1101/2021.03.05.21252989; this version posted March 12, 2021. The copyright holder for this preprint (which was not certified by peer review) is the author/funder, who has granted medRxiv a license to display the preprint in perpetuity. It is made available under a CC-BY-NC-ND 4.0 International license .

589

590

591

592

593

594

595

596

597

598

599

600

601

602

603

604

605

606

607

608

609

610

27. Hoffman, G. E. \& Schadt, E. E. variancePartition: interpreting drivers of variation in complex gene expression studies. BMC Bioinformatics 17, 483 (2016).

28. Law, C. W., Chen, Y., Shi, W. \& Smyth, G. K. voom: precision weights unlock linear model analysis tools for RNA-seq read counts. Genome Biol. 15, R29 (2014).

29. Mellon, S. H., Gautam, A., Hammamieh, R., Jett, M. \& Wolkowitz, O. M. Metabolism, Metabolomics, and Inflammation in Posttraumatic Stress Disorder. Biol. Psychiatry 83, 866875 (2018).

30. Wisnivesky, J. P. et al. Persistence of multiple illnesses in World Trade Center rescue and recovery workers: a cohort study. Lancet Lond. Engl. 378, 888-897 (2011).

31. Benjamini, Y. \& Hochberg, Y. Controlling the False Discovery Rate: A Practical and Powerful Approach to Multiple Testing. J. R. Stat. Soc. Ser. B Methodol. 57, 289-300 (1995).

32. Bild, A. \& Febbo, P. G. Application of a priori established gene sets to discover biologically important differential expression in microarray data. Proc. Natl. Acad. Sci. 102, 1527815279 (2005).

33. Korotkevich, G., Sukhov, V. \& Sergushichev, A. Fast gene set enrichment analysis. bioRxiv 060012 (2019) doi:10.1101/060012.

34. How to do GSEA in R with (fgsea or gage) and plot results. Bioinformatics Breakdown https://bioinformaticsbreakdown.com/how-to-gsea/ (2019).

35. Kanehisa, M., Sato, Y., Kawashima, M., Furumichi, M. \& Tanabe, M. KEGG as a reference

resource for gene and protein annotation. Nucleic Acids Res. 44, D457-D462 (2016).

36. Yu, G., Wang, L.-G., Han, Y. \& He, Q.-Y. clusterProfiler: an R Package for Comparing Biological Themes Among Gene Clusters. OMICS J. Integr. Biol. 16, 284-287 (2012). 
medRxiv preprint doi: https://doi.org/10.1101/2021.03.05.21252989; this version posted March 12, 2021. The copyright holder for this preprint (which was not certified by peer review) is the author/funder, who has granted medRxiv a license to display the preprint in perpetuity. It is made available under a CC-BY-NC-ND 4.0 International license .

611 37. Willer, C. J., Li, Y. \& Abecasis, G. R. METAL: fast and efficient meta-analysis of genomewide

612 association scans. Bioinformatics 26, 2190-2191 (2010).

613 38. Newman, A. M. et al. Robust enumeration of cell subsets from tissue expression profiles.

$614 \quad$ Nat. Methods 12, 453-457 (2015).

615 39. Daskalakis, N. P., Rijal, C. M., King, C., Huckins, L. M. \& Ressler, K. J. Recent Genetics and 616 Epigenetics Approaches to PTSD. Curr. Psychiatry Rep. 20, 30 (2018).

617 40. Neigh, G. N. \& Ali, F. F. Co-Morbidity of PTSD and Immune System Dysfunction:

618 Opportunities for Treatment. Curr. Opin. Pharmacol. 29, 104-110 (2016).

619 41. Wang, Z., Caughron, B. \& Young, M. R. I. Posttraumatic Stress Disorder: An Immunological

620 Disorder? Front. Psychiatry 8, (2017).

621 42. Speer, K. E., Semple, S., Naumovski, N., D’Cunha, N. M. \& McKune, A. J. HPA axis function 622 and diurnal cortisol in post-traumatic stress disorder: A systematic review. Neurobiol. Stress

623 11, (2019).

624 43. Yehuda, R. et al. Post-traumatic stress disorder. Nat. Rev. Dis. Primer 1, 1-22 (2015).

625 44. Nutt, D. J. \& Malizia, A. L. Structural and functional brain changes in posttraumatic stress

626 disorder. J. Clin. Psychiatry 65 Suppl 1, 11-17 (2004).

627 45. Duncan, L. E. et al. Largest GWAS of PTSD ( $N=20$ ? 070$)$ yields genetic overlap with

628 schizophrenia and sex differences in heritability. Mol. Psychiatry 23, 666-673 (2018).

629 46. Li, Z. et al. Genome-wide association analysis identifies 30 new susceptibility loci for

630 schizophrenia. Nat. Genet. 49, 1576-1583 (2017).

631 47. Jong, S. de et al. Immune signatures and disorder-specific patterns in a cross-disorder gene 632 expression analysis. Br. J. Psychiatry 209, 202-208 (2016). 
medRxiv preprint doi: https://doi.org/10.1101/2021.03.05.21252989; this version posted March 12, 2021. The copyright holder for this preprint (which was not certified by peer review) is the author/funder, who has granted medRxiv a license to display the preprint in perpetuity.

It is made available under a CC-BY-NC-ND 4.0 International license .

633 48. Tsolakidou, A. et al. Gene expression profiling in the stress control brain region

634 hypothalamic paraventricular nucleus reveals a novel gene network including Amyloid beta Precursor Protein. BMC Genomics 11, 546 (2010).

49. Maccarrone, G. et al. Psychiatric patient stratification using biosignatures based on cerebrospinal fluid protein expression clusters. J. Psychiatr. Res. 47, 1572-1580 (2013).

50. Hou, Y. et al. Schizophrenia-associated rs4702 G allele-specific downregulation of FURIN expression by miR-338-3p reduces BDNF production. Schizophr. Res. 199, 176-180 (2018).

51. Schrode, N. et al. Synergistic effects of common schizophrenia risk variants. Nat. Genet. 51, 1475-1485 (2019).

52. English, J. A. et al. Reduced protein synthesis in schizophrenia patient-derived olfactory cells. Transl. Psychiatry 5, e663-e663 (2015).

53. Miron, J. et al. Association of PPP2R1A with Alzheimer's disease and specific cognitive domains. Neurobiol. Aging 81, 234-243 (2019).

54. Bralten, J. et al. Candidate Genetic Pathways for Attention-Deficit/Hyperactivity Disorder (ADHD) Show Association to Hyperactive/Impulsive Symptoms in Children With ADHD. J. mRNA Expression in Alzheimer's Disease. Med. Sci. Monit. Int. Med. J. Exp. Clin. Res. 23, $2721-2731(2017)$ exposed to chronic psychological stress. Biol. Psychol. 76, 147-155 (2007). 
medRxiv preprint doi: https://doi.org/10.1101/2021.03.05.21252989; this version posted March 12, 2021. The copyright holder for this preprint (which was not certified by peer review) is the author/funder, who has granted medRxiv a license to display the preprint in perpetuity. It is made available under a CC-BY-NC-ND 4.0 International license .

654

655

656

657

658

659

660

661

662

663

664

665

666

667

668

669

670

671

672

673

57. Zhao, Y. et al. A large-scale integrative analysis of GWAS and common meQTLs across whole life course identifies genes, pathways and tissue/cell types for three major psychiatric disorders. Neurosci. Biobehav. Rev. 95, 347-352 (2018).

58. Konno, T. et al. DCTN1-related neurodegeneration: Perry syndrome and beyond. Parkinsonism Relat. Disord. 41, 14-24 (2017).

59. Seth, A., Giunta, S., Franceschil, C., Kola, I. \& Venanzoni, M. C. Regulation of the human stress response gene GADD153 expression: role of ETS1 and FLI-1 gene products. Cell Death Differ. 6, 902-907 (1999).

60. St-Louis, É. et al. Involvement of the coatomer protein complex I in the intracellular traffic of the delta opioid receptor. Mol. Cell. Neurosci. 79, 53-63 (2017).

61. Bettayeb, K. et al. Relevance of the COPI complex for Alzheimer's disease progression in vivo. Proc. Natl. Acad. Sci. U. S. A. 113, 5418-5423 (2016).

62. Yang, Y., Wang, X., Ju, W., Sun, L. \& Zhang, H. Genetic and Expression Analysis of COPI Genes and Alzheimer's Disease Susceptibility. Front. Genet. 10, 866 (2019).

63. Izumi, K. et al. ARCN1 Mutations Cause a Recognizable Craniofacial Syndrome Due to COPIMediated Transport Defects. Am. J. Hum. Genet. 99, 451-459 (2016).

64. Watkin, L. B. et al. COPA mutations impair ER-Golgi transport and cause hereditary autoimmune-mediated lung disease and arthritis. Nat. Genet. 47, 654-660 (2015).

65. Jean, F., Stuart, A. \& Tarailo-Graovac, M. Dissecting the Genetic and Etiological Causes of 
medRxiv preprint doi: https://doi.org/10.1101/2021.03.05.21252989; this version posted March 12, 2021. The copyright holder for this preprint (which was not certified by peer review) is the author/funder, who has granted medRxiv a license to display the preprint in perpetuity. It is made available under a CC-BY-NC-ND 4.0 International license .

674 66. Lippmann, M., Cohen, M. D. \& Chen, L.-C. Health effects of World Trade Center (WTC) Dust:

675 An unprecedented disaster with inadequate risk management. Crit. Rev. Toxicol. 45, 492$676530(2015)$

677 67. Reibman, J. et al. Characteristics of a Residential and Working Community With Diverse 678 Exposure to World Trade Center Dust, Gas, and Fumes. J. Occup. Environ. Med. Am. Coll. 679 Occup. Environ. Med. 51, 534-541 (2009).

680 68. Hervé, M. et al. Translational Identification of Transcriptional Signatures of Major 681 Depression and Antidepressant Response. Front. Mol. Neurosci. 10, (2017).

682 69. Carlini, V. et al. CLIC1 Protein Accumulates in Circulating Monocyte Membrane during 683 Neurodegeneration. Int. J. Mol. Sci. 21, (2020).

684 70. Tang, T. et al. CLICs-dependent chloride efflux is an essential and proximal upstream event 685 for NLRP3 inflammasome activation. Nat. Commun. 8, 202 (2017).

686 71. Gurunathan, G., Yu, Z., Coulombe, Y., Masson, J.-Y. \& Richard, S. Arginine methylation of hnRNPUL1 regulates interaction with NBS1 and recruitment to sites of DNA damage. Sci. Rep. 5, 10475 (2015).

72. Baker, K. et al. Neonatal Fc receptor for IgG (FcRn) regulates cross-presentation of IgG immune complexes by CD8-CD11b+ dendritic cells. Proc. Natl. Acad. Sci. U. S. A. 108, 9927-

692 73. Le-Niculescu, H. et al. Towards precision medicine for stress disorders: diagnostic 693 biomarkers and targeted drugs. Mol. Psychiatry 25, 918-938 (2020).

694 74. Zhu, X., Bührer, C. \& Wellmann, S. Cold-inducible proteins CIRP and RBM3, a unique couple 695 with activities far beyond the cold. Cell. Mol. Life Sci. 73, 3839-3859 (2016). 
medRxiv preprint doi: https://doi.org/10.1101/2021.03.05.21252989; this version posted March 12, 2021. The copyright holder for this preprint (which was not certified by peer review) is the author/funder, who has granted medRxiv a license to display the preprint in perpetuity. It is made available under a CC-BY-NC-ND 4.0 International license .

75. Zhou, J.-Y. et al. Trauma-associated Human Neutrophil Alterations Revealed by Comparative Proteomics Profiling. Proteomics Clin. Appl. 7, (2013).

76. Lu, Q., Shen, N., Li, X. M. \& Chen, S. L. Genomic view of IFN- $\alpha$ response in pre-autoimmune NZB/W and MRL/Ipr mice. Genes Immun. 8, 590-603 (2007).

77. Chen, Y., Li, X., Kobayashi, I., Tsao, D. \& Mellman, T. A. Expression and methylation in posttraumatic stress disorder and resilience; evidence of a role for odorant receptors. Psychiatry Res. 245, 36-44 (2016).

78. Breen, M. S. et al. Differential transcriptional response following glucocorticoid activation in cultured blood immune cells: a novel approach to PTSD biomarker development. Transl. Psychiatry 9, 201 (2019).

79. Glover, D. A., Steele, A. C., Stuber, M. L. \& Fahey, J. L. Preliminary evidence for lymphocyte distribution differences at rest and after acute psychological stress in PTSD-symptomatic women. Brain. Behav. Immun. 19, 243-251 (2005).

80. Lemieux, A., Coe, C. L. \& Carnes, M. Symptom severity predicts degree of T cell activation in adult women following childhood maltreatment. Brain. Behav. Immun. 22, 994-1003

81. Skapenko, A., Leipe, J., Lipsky, P. E. \& Schulze-Koops, H. The role of the T cell in autoimmune inflammation. Arthritis Res. Ther. 7, S4-S14 (2005).

714 82. Baumeister, D., Akhtar, R., Ciufolini, S., Pariante, C. M. \& Mondelli, V. Childhood trauma and 715 adulthood inflammation: a meta-analysis of peripheral C-reactive protein, interleukin- 6 and tumour necrosis factor- $\alpha$. Mol. Psychiatry 21, 642-649 (2016). 
medRxiv preprint doi: https://doi.org/10.1101/2021.03.05.21252989; this version posted March 12, 2021. The copyright holder for this preprint (which was not certified by peer review) is the author/funder, who has granted medRxiv a license to display the preprint in perpetuity. It is made available under a CC-BY-NC-ND 4.0 International license.

717 83. Dong, Y. et al. Stress-induced NLRP3 inflammasome activation negatively regulates fear

718 memory in mice. J. Neuroinflammation 17, 205 (2020).

719 84. Fonkoue, I. T. et al. Symptom severity impacts sympathetic dysregulation and inflammation

720 in post-traumatic stress disorder (PTSD). Brain. Behav. Immun. 83, 260-269 (2020).

721 85. Michopoulos, V., Powers, A., Gillespie, C. F., Ressler, K. J. \& Jovanovic, T. Inflammation in

722 Fear- and Anxiety-Based Disorders: PTSD, GAD, and Beyond. Neuropsychopharmacology 42,

$723 \quad 254-270(2017)$.

724 86. Speer, K., Upton, D., Semple, S. \& McKune, A. Systemic low-grade inflammation in post-

725 traumatic stress disorder: a systematic review. J. Inflamm. Res. 11, 111-121 (2018). 
Table 1. Demographic and Other Characteristics

$\begin{array}{lcc} & \text { Mean (SD) or N (\%) } & \\ \text { Age (years) } & 54.1(8.3) & \text { Mean (SD) } \\ \text { Number of years post-9/11 sample collected } & 13(2.3) & \text { Mean (SD) } \\ \text { BMI } & 30.1(5.9) & \text { Mean (SD) } \\ \text { Male sex } & 291(82) & N(\%) \\ \text { Current smoker } & 22(6.2) & N(\%) \\ \text { High school graduate } & 301(84.9) & N(\%) \\ \text { Annual income }>\$ 90,000 & 178(50.1) & N(\%) \\ \text { Responder type } & & \\ \text { Police responder } & 145(40.8) & N(\%) \\ \text { Non-traditional responder } & 210(59.2) & N(\%) \\ \text { Race-ethnicity } & & \\ \text { African American } & 64(18) & N(\%) \\ \text { Asian } & 5(1.4) & N(\%) \\ \text { Hispanic } & 72(20.3) & N(\%) \\ \text { Native American } & 9(2.5) & N(\%) \\ \text { European American (White) } & 216(60.8) & N(\%) \\ \quad \text { Other } & 8(2.3) & N(\%)\end{array}$

Note: $\mathrm{SD}=$ standard deviation; $\mathrm{BMI}=$ body mass index; $\mathrm{n}=355$ 
Table 2. Gene Expression Studies Included in Meta-Analysis

\begin{tabular}{lccccccc} 
Trauma Study & ISMMS & WTC-d & WTC-r & TMA-C & TMA-M & TM $^{\mathbf{1 2}}$ & TMA-FI $^{\mathbf{1 2}}$ \\
Past-month PTSD/control, N subjects & $53 / 302$ & $57 / 138$ & $24 / 63$ & N/A & N/A & N/A \\
Lifetime PTSD/Control, N subjects & $108 / 247$ & N/A & N/A & $85 / 84$ & $45 / 67$ & $99 / 160$ \\
Total N subjects & 355 & 195 & 87 & 169 & 112 & 259 \\
Available genes (p<0.05), N & 1016 & 27 & 27 & 806 & 418 & 418 \\
Age, Mean & $54.1(8.3)$ & $52(8.12)$ & $52(8.12)$ & $24.4(4.7)$ & $41.1(12.8)$ & $39.5(12.3)$ \\
Male, N (\%) & $291(82)$ & $195(100)$ & $87(100)$ & $169(100)$ & $112(100)$ & $0(0)$ \\
European American, N (\%) & $216(60.8)$ & $165(84.6)$ & $74(84.6)$ & $108(63.6)$ & $34(30.3)$ & $62(23.9)$ \\
African American, N (\%) & $64(18)$ & N/A & N/A & N/A & $78(69.7)$ & $197(76.1)$ \\
Hispanic, N (\%) & $72(20.3)$ & N/A & N/A & N/A & N/A & N/A \\
\hline
\end{tabular}

Note: ISMMS=Icahn School of Medicine at Mount Sinai (this study);WTC-d=Stony Brook World Trade Center discovery cohort; WTC-r=Stony Brook World Trade Center replication cohort; TMA-C=Trauma mega-analysis combat cohort; TMA-MI=Trauma mega-analysis male-interpersonal cohort; TMA-FI=Trauma mega-analysis female-interpersonal cohort. ${ }^{3}$ Kuan PF et al 2017,

${ }^{12}$ Breen MS et al 2018. 
Table 3. Bivariate Correlations Between Lifetime and Past-month Total CAPS Scores and PTSD Symptom Dimensions

\begin{tabular}{|l|c|c|c|c|c|}
\hline Lifetime vs. Past-month & $\mathbf{R}^{\mathbf{2}}$ (of beta values) & $\mathbf{p}$ & $\mathbf{R}^{\mathbf{2}}$ (of FDR-adjusted P values) & $\mathbf{p}$ & \\
\hline Total CAPS score & 0.82 & $<2.2 \times 10-16$ & 0.79 & $<2.2 \times 10-16$ & \\
\hline Re-experiencing & 0.66 & $<2.2 \times 10-16$ & 0.63 & $<2.2 \times 10-16$ & \\
\hline Anxious Arousal & 0.8 & $<2.2 \times 10-16$ & 0.77 & $<2.2 \times 10-16$ & \\
\hline Avoidance & 0.73 & $<2.2 \times 10-16$ & 0.71 & $<2.2 \times 10-16$ & \\
\hline Dysphoric Arousal & 0.75 & $<2.2 \times 10-16$ & 0.72 & $<2.2 \times 10-16$ & \\
\hline Numbing & 0.66 & $<2.2 \times 10-16$ & 0.64 & \\
\hline
\end{tabular}

\section{Bivariate Correlations Between PTSD Symptom Dimensions}

\begin{tabular}{|c|c|c|c|c|c|}
\hline Past-month & Re-experiencing & Anxious Arousal & Avoidance & Dysphoric Arousal & Numbing \\
\hline Re-experiencing & 1 & 0.53 & 0.63 & 0.59 & 0.62 \\
\hline Anxious Arousal & & 1 & 0.57 & 0.64 & 0.55 \\
\hline Avoidance & & & 1 & 0.61 & 0.63 \\
\hline Dysphoric Arousal & & & & 1 & 0.71 \\
\hline Numbing & & & & & 1 \\
\hline Lifetime & Re-experiencing & Anxious Arousal & Avoidance & Dysphoric Arousal & Numbing \\
\hline Re-experiencing & 1 & 0.72 & 0.79 & 0.75 & 0.73 \\
\hline Anxious Arousal & & 1 & 0.71 & 0.73 & 0.69 \\
\hline Avoidance & & & 1 & 0.74 & 0.79 \\
\hline Dysphoric Arousal & & & & 1 & 0.78 \\
\hline Numbing & & & & & 1 \\
\hline
\end{tabular}

Note: CAPS = Clinician-Administered PTSD Scale; FDR = false discovery rate. 
Table 4. Comorbid Medical Conditions

\begin{tabular}{lc}
\hline Conditions & $\mathbf{N}(\%)$ \\
Hypertension & $162(45.6)$ \\
Cardiac disease & $28(7.9)$ \\
Diabetes & $44(12.4)$ \\
GERD & $184(51.8)$ \\
Chronic pain & $144(40.6)$ \\
Arthritis & $138(38.9)$ \\
Asthma & $161(45.4)$ \\
Cancer & $51(14.4)$ \\
Chronic rhinitis & $169(47.6)$ \\
Sleep apnea & $127(35.8)$ \\
Kidney disease & $8(2.3)$ \\
Chronic skin condition & $70(19.7)$ \\
High cholesterol & $174(49)$ \\
Liver disease & $15(4.3)$ \\
Migraine & $50(14.1)$ \\
Osteoporosis & $11(3.1)$ \\
Rheumatoid Arthritis & $15(4.3)$ \\
Stroke & $4(1.1)$ \\
Traumatic brain injury & $5(1.4)$ \\
\hline
\end{tabular}

Note: GERD = gastroesophageal reflux disease. 
Table 5. Meta-analysis of Study Results With Five Publicly Available Cohorts

Lifetime PTSD

\begin{tabular}{|c|c|c|c|c|c|c|c|c|}
\hline Marker Name & Weight & Z-score & P-value & Direction & $\begin{array}{c}\text { Heterogenous I- } \\
\text { Squared }\end{array}$ & $\begin{array}{l}\text { Heterogenous } \\
\text { Chi-Squared }\end{array}$ & $\begin{array}{l}\text { Heterogenous } \\
\text { degrees of freedom }\end{array}$ & $\begin{array}{l}\text { Heterogenous } \\
\text { P value }\end{array}$ \\
\hline COPE & 524 & -5.277 & 1.31E-07 & $-? ?-? ?$ & 91.7 & 12.103 & 1 & 0.0005034 \\
\hline CIRBP & 982 & -4.842 & $1.29 \mathrm{E}-06$ & --?--- & 0 & 3.785 & 4 & 0.4358 \\
\hline TMSB10 & 442 & -4.516 & $6.31 \mathrm{E}-06$ & --???? & 32 & 1.47 & 1 & 0.2253 \\
\hline FCGRT & 1177 & -4.392 & $1.12 \mathrm{E}-05$ & ----+- & 52 & 10.423 & 5 & 0.06411 \\
\hline ALDOA & 895 & -4.072 & $4.66 \mathrm{E}-05$ & -??--- & 43.2 & 5.281 & 3 & 0.1523 \\
\hline RPS6KB2 & 1177 & -4.14 & 3.47E-05 & -----+ & 50.5 & 10.099 & 5 & 0.07248 \\
\hline HNRNPUL1 & 355 & -4.103 & $4.08 \mathrm{E}-05$ & -????? & 0 & 0 & 0 & 1 \\
\hline CLIC1 & 355 & -4.276 & $1.90 \mathrm{E}-05$ & -????? & 0 & 0 & 0 & 1 \\
\hline
\end{tabular}

Past-month PTSD

\begin{tabular}{|c|c|c|c|c|c|c|c|c|}
\hline Marker Name & Weight & Z-score & P-value & Direction & $\begin{array}{l}\text { Heterogenous I- } \\
\text { Squared }\end{array}$ & $\begin{array}{l}\text { Heterogenous } \\
\text { Chi-Squared }\end{array}$ & $\begin{array}{c}\text { Heterogenous } \\
\text { degrees of freedom }\end{array}$ & $\begin{array}{l}\text { Heterogenous } \\
\text { P value }\end{array}$ \\
\hline COPE & 524 & -4.778 & $1.77 \mathrm{E}-06$ & -??-?? & 89.8 & 9.826 & 1 & 0.00172 \\
\hline CIRBP & 982 & -5.016 & $5.27 \mathrm{E}-07$ & $--?--$ & 0 & 3.676 & 4 & 0.4516 \\
\hline FCGRT & 1177 & -4.793 & $1.64 \mathrm{E}-06$ & -----+ & 59.9 & 12.475 & 5 & 0.02883 \\
\hline ZNF439 & 451 & -4.574 & $4.78 \mathrm{E}-06$ & ?---?? & 0 & 1.695 & 2 & 0.4285 \\
\hline NACA & 355 & -4.649 & $3.34 \mathrm{E}-06$ & -????? & 0 & 0 & 0 & 1 \\
\hline
\end{tabular}

Note: CAPS-5 = Clinician-Administered PTSD Scale. Direction is defined as our study, WTC discovery cohort ${ }^{3}$, WTC replication cohort ${ }^{3}$, military trauma, male interpersonal trauma and female interpersonal trauma (from mega-analysis study ${ }^{12}$ ). ${ }^{3} \mathrm{Kuan}$ PF et al $2017,{ }^{12} \mathrm{Breen} \mathrm{MS}$ et al 2018. 
medRxiv preprint doi: https://doi.org/10.1101/2021.03.05.21252989; this version posted March 12, 2021. The copyright holder for this preprint (which was not certified by peer review) is the author/funder, who has granted medRxiv a license to display the preprint in perpetuity. It is made available under a CC-BY-NC-ND 4.0 International license .

Figure 1. Number of World Trade Center first respondents who completed the study with viable RNA-sequencing data, $\mathrm{N}=355$.

Figure 2. Distribution of lifetime and past-month severity scores for (A) CAPS, (B) numbing, (C) avoidance, (D) re-experiencing, (E) anxious arousal and (F) dysphoric arousal. PTSD symptom dimensions are scored from 0-50, and CAPS is an aggregate of that score. Total N=355 World Trade Center responders.

Figure 3. Differential gene expression analysis of A) lifetime CAPS B) CAPS past-month C) anxious arousal lifetime and $\mathrm{d}$ ) anxious arousal past-month in $\mathrm{N}=355$ World Trade Center firstresponders. Total number of differentially expressed genes $(p<0.05)$ : A) $N=66, B) N=31, C$ ) $\mathrm{N}=86$, D) $\mathrm{N}=61$. Phenotypes were corrected for sex, age, batch, and first 10 ancestry principal components.

Figure 4. Dust cloud severity (A-B) and disease comorbidity (C-D) of CAPS lifetime and pastmonth genome-wide correlations. (E) Interaction term, STX10, of disease comorbidity and CAPS lifetime. SumMed: summary of medical terms for disease comorbidity; CAPS-LT: CAPS lifetime.

Figure 5. Heatmap of differentially expressed $(p<0.05)$ genes from a gene expression analysis across (A) past-month CAPS and symptom dimensions and (B) lifetime CAPS and symptom dimensions in N=355 World Trade Center first-responders. Phenotypes were corrected for sex, age, batch, and first 10 ancestry principal components. Gene clusters represent genealogical expression diversity among lifetime total CAPS and symptom dimensions.

Figure 6. KEGG pathway enrichment of differentially expressed genes in $\mathrm{N}=355$ World Trade Center first-responders in (A) past-month and (B) lifetime CAPS. Pathways categorically grouped by metabolic, immune signaling, innate immunity, structural, hormonal/neurological, regenerative and psychiatric function.

Figure 7. Forestplots (A-E) and volcano plot (F) of genome-wide significant genes from our meta-analysis. Meta-analysis included our gene expression analysis, another World Trade Center (WTC) study, and a mega-analysis of 7 different compiled trauma studies.

Figure 8. Cellular deconvolution of immune cells in peripheral blood. Significant cell type differences for CAPS lifetime and past-month compared to controls are noted.

Table 1. Demographic information of $\mathbf{N}=\mathbf{3 5 5}$ World Trade Center first responders

Table 2. Medical comorbidities and corresponding $\mathbf{N}$ of World Trade Center first responders with each comorbidity.

Table 3. Significant $(p<0.05)$ genes associated with each phenotype and corresponding statistical values: $\log 2$ fold change, average expression, $t$-statistic, $p$ value, FDR-corrected $p$ 
medRxiv preprint doi: https://doi.org/10.1101/2021.03.05.21252989; this version posted March 12, 2021. The copyright holder for this preprint (which was not certified by peer review) is the author/funder, who has granted medRxiv a license to display the preprint in perpetuity. It is made available under a CC-BY-NC-ND 4.0 International license .

value, and beta value. Phenotypes included are lifetime CAPS and past-month CAPS and all symptom dimensions.

Table 4. PTSD and demographic information of meta-analysis study. Includes Stony Brook World Trade Center cohort and a mega-analysis study split into combat, male interpersonal and female interpersonal trauma.

Table 5. Table of genome-wide significant genes from our meta-analysis for lifetime and pastmonth PTSD. Meta-analysis included our gene expression analysis, another World Trade Center (WTC) study, and a mega-analysis of 7 different compiled trauma studies. Direction is defined as our study, WTC discovery cohort, WTC replication cohort, military trauma, male interpersonal trauma and female interpersonal trauma (from the mega-analysis study).

Supplemental Table 2. (A) Correlations of beta values and FDR-adjusted $p$ values for CAPS lifetime versus past-month and all associated symptom dimensions. (B) Correlations of symptom dimensions against all other symptom dimensions for past-month and (C) lifetime. All correlations were significant $\left(p<2.2 \times 10^{-16}\right)$. 
medRxiv preprint doi: https://doi.org/10.1101/2021.03.05.21252989; this version posted March 12, 2021. The copyright holder for this preprint (which was not certified by peer review) is the author/funder, who has granted medRxiv a license to display the preprint in perpetuity. It is made available under a CC-BY-NC-ND 4.0 International license .

\section{WTC Responders contacted}

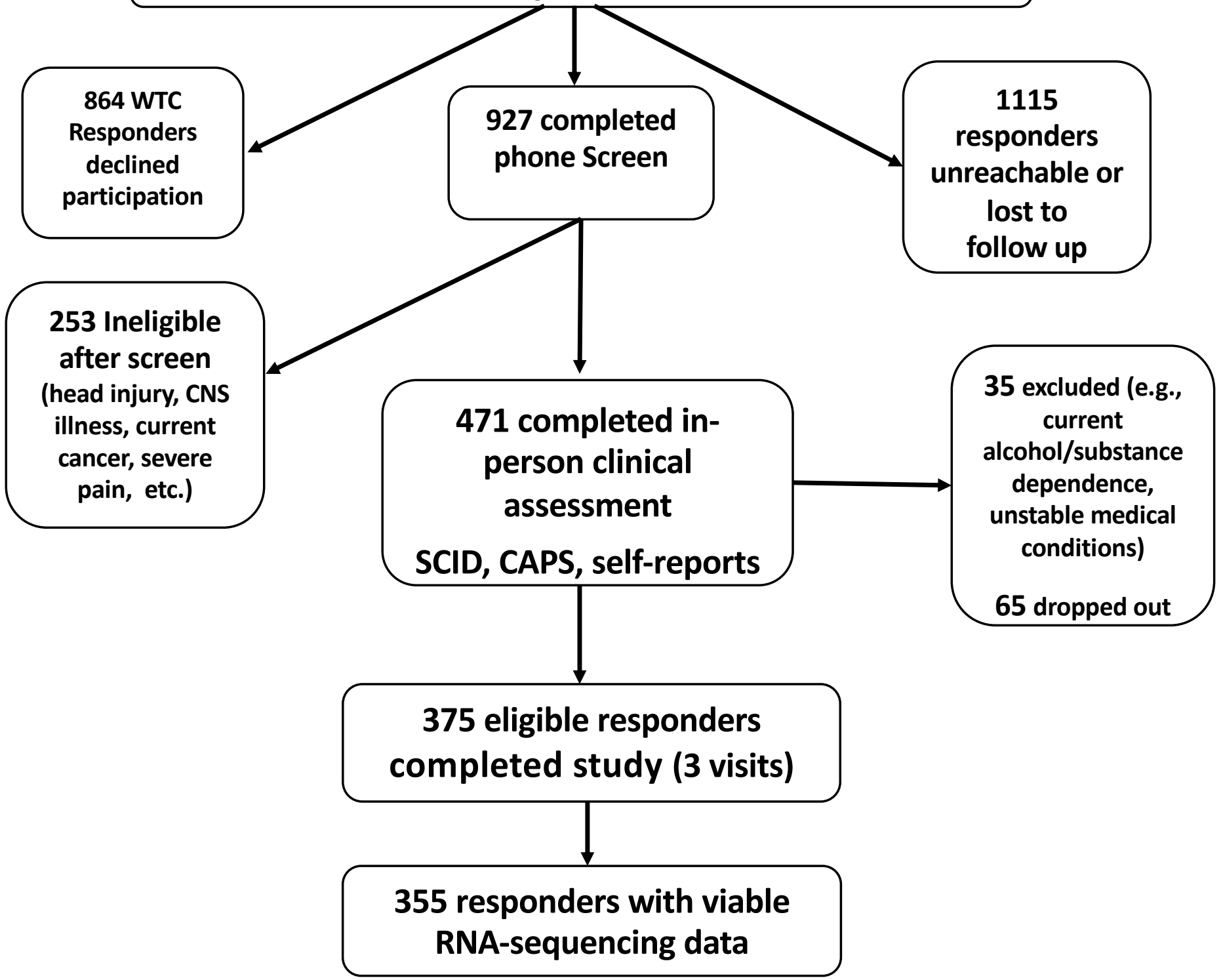


medRxiv preprint doi: https://doi.org/10.1101/2021.03.05.21252989; this version posted March 12, 2021. The copyright holder for this preprint (which was not certified by peer review) is the author/funder, who has granted medRxiv a license to display the preprint in perpetuity.

A.

CAPS
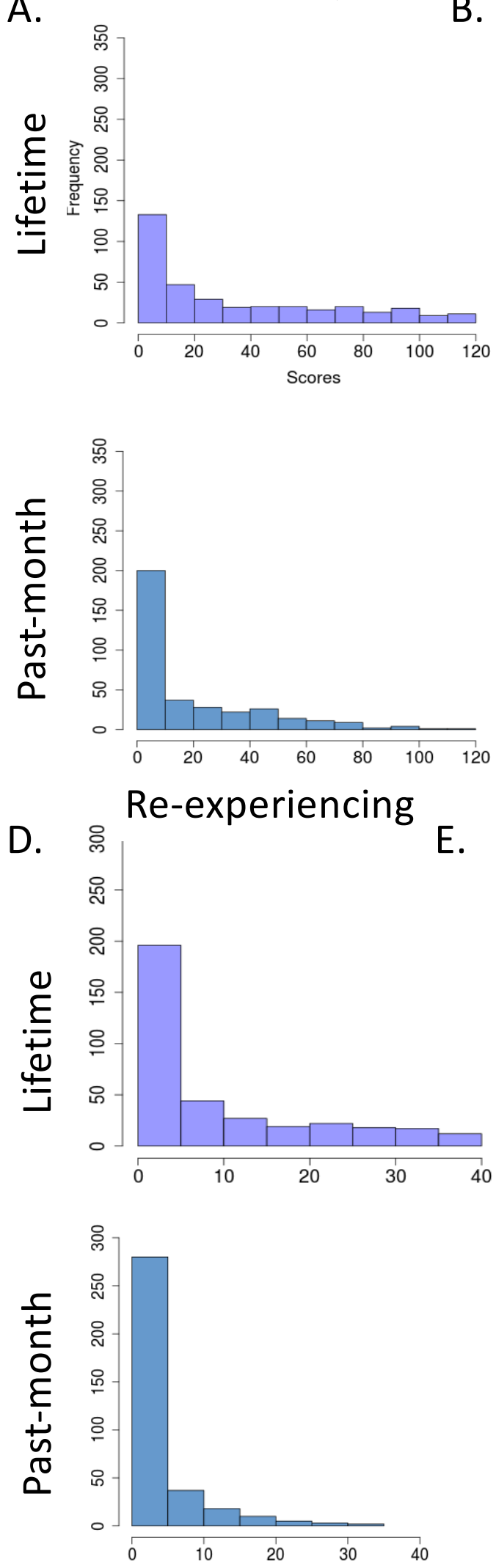

Numbing
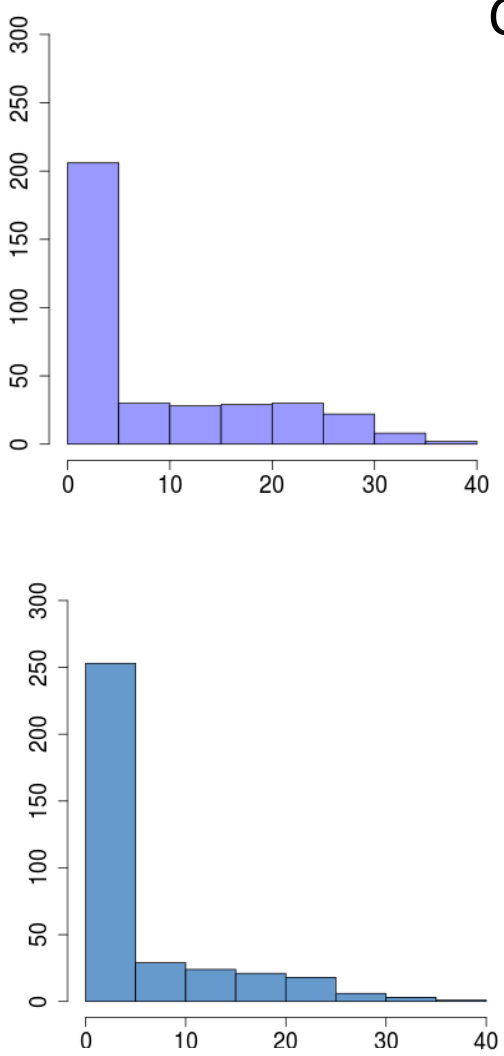

Anxious Arousal
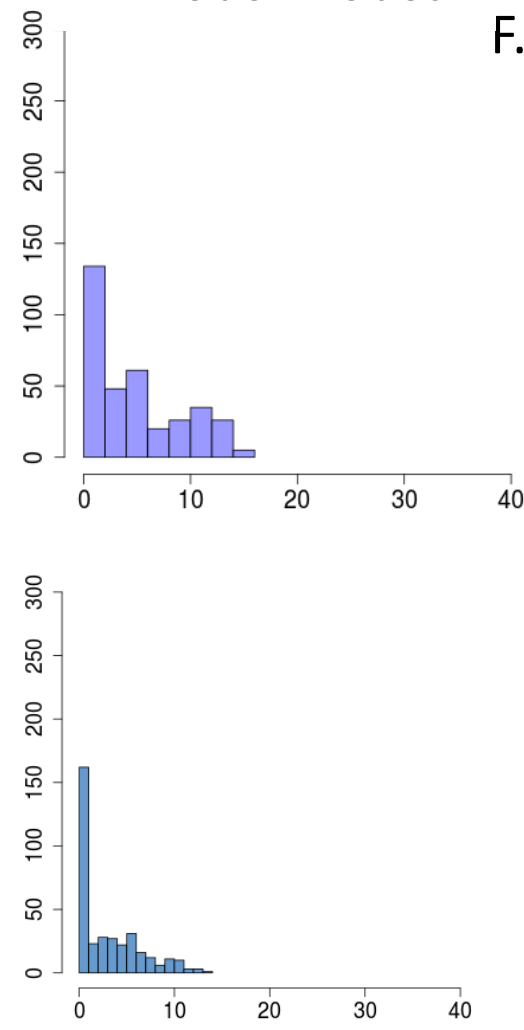

\section{F.}

Avoidance

C. $\stackrel{8}{0}$
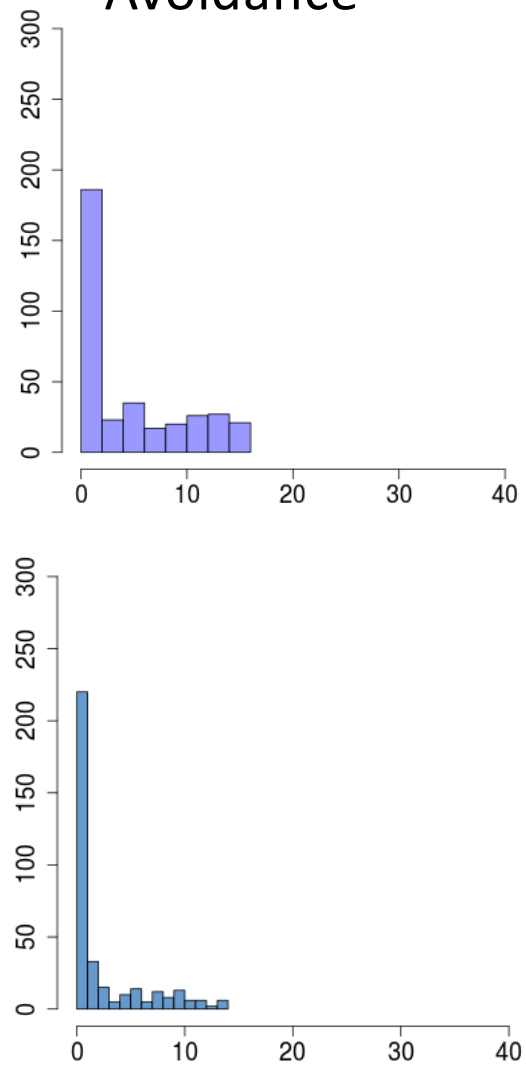

Dysphoric Arousal
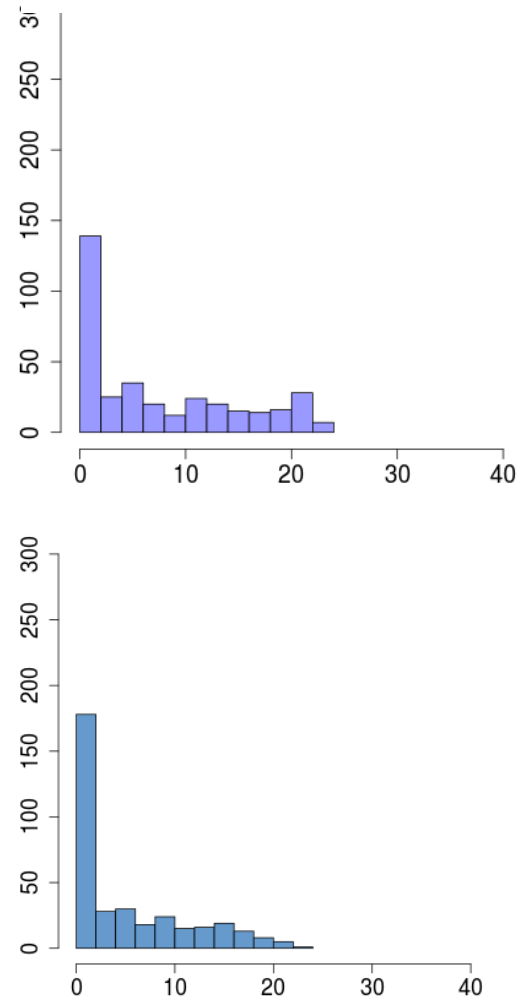
A. Total Lifetime CAPS Score

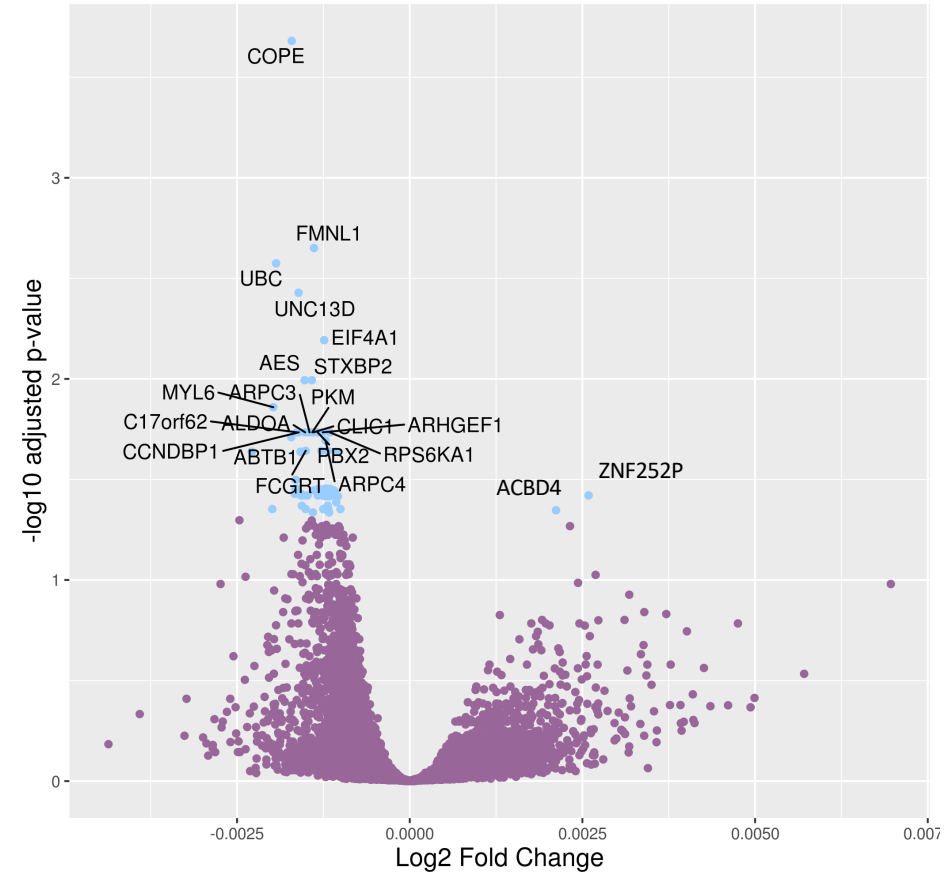

C. Lifetime Anxious Arousal

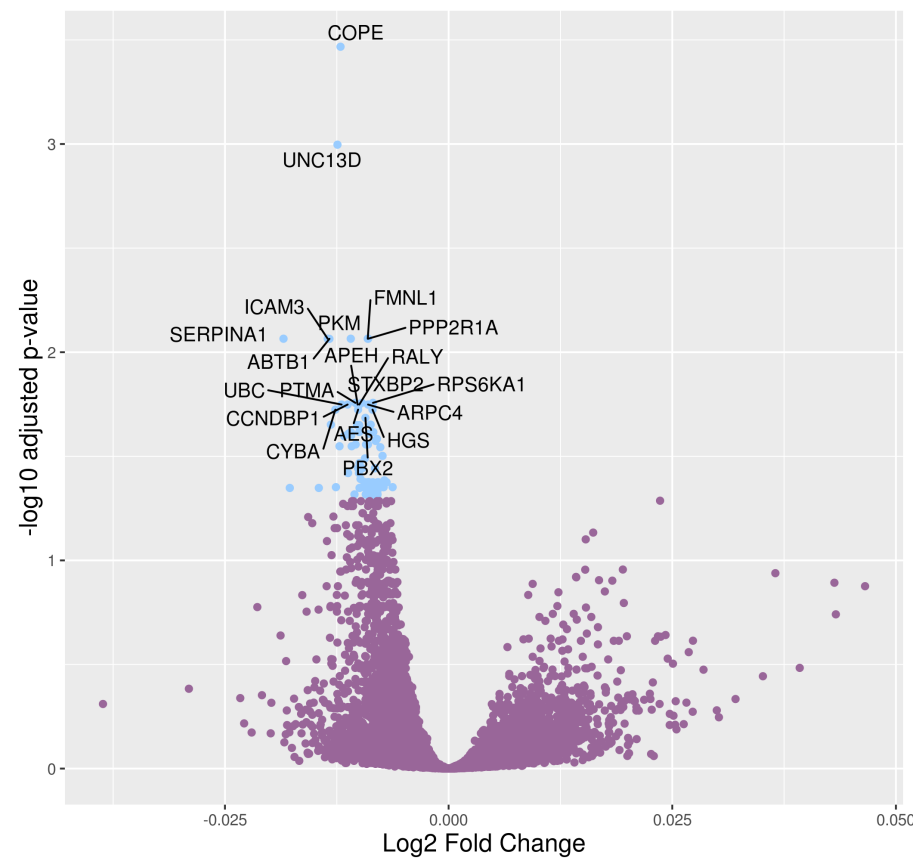

B. Total Past-month CAPS Score

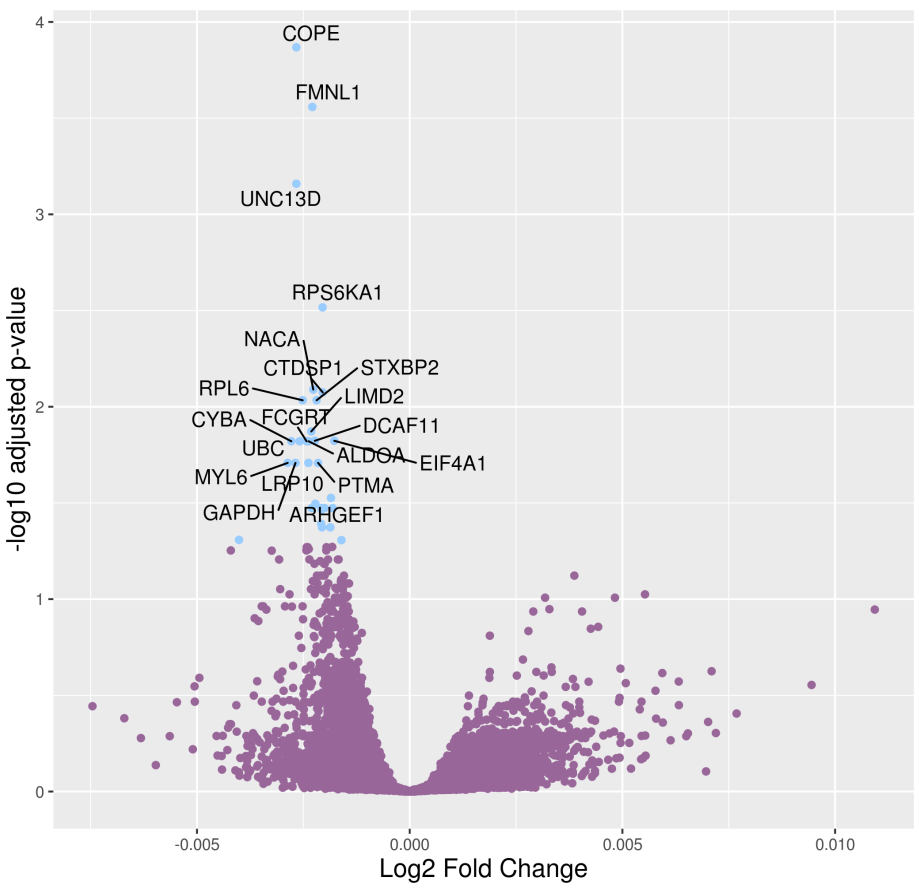

D. Past-month Anxious Arousal

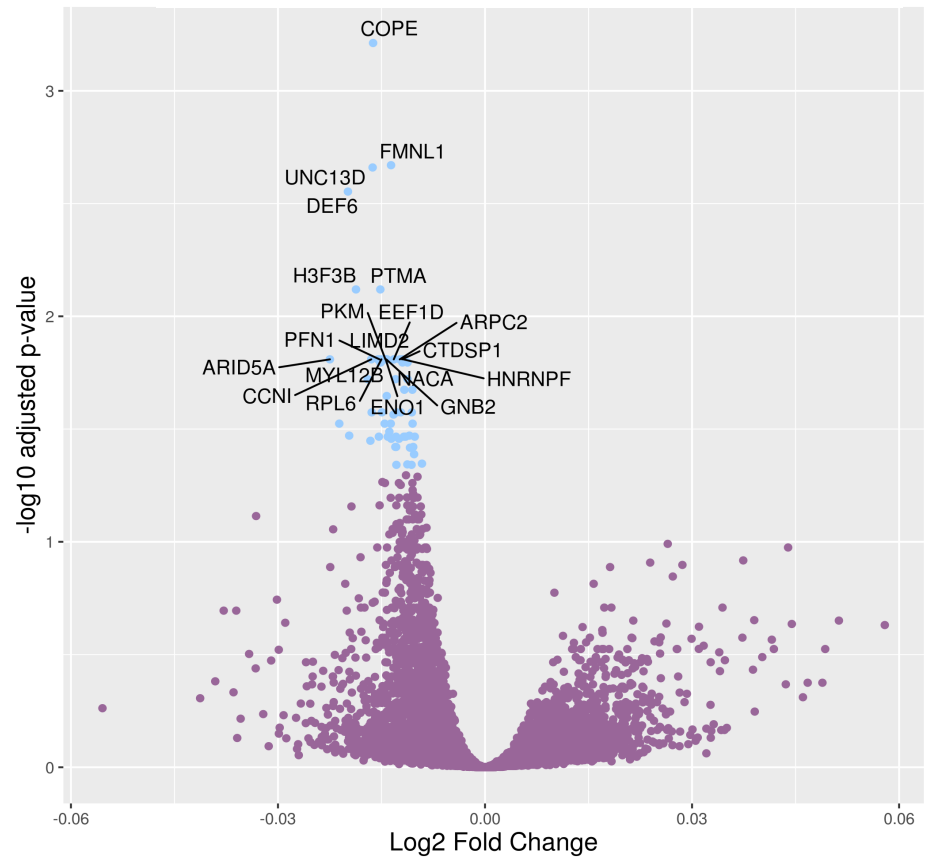


medRxiv preprint doi: https://doi.org/10.1101/2021.03.05.21252989; this version posted March 12, 2021. The copyright holder for this preprint (which was not certified by peer review) is the author/funder, who has granted medRxiv a license to display the preprint in perpetuity. It is made available under a CC-BY-NC-ND 4.0 International license .

\section{A. Total Lifetime CAPS Score B. Total Past-month CAPS Score}
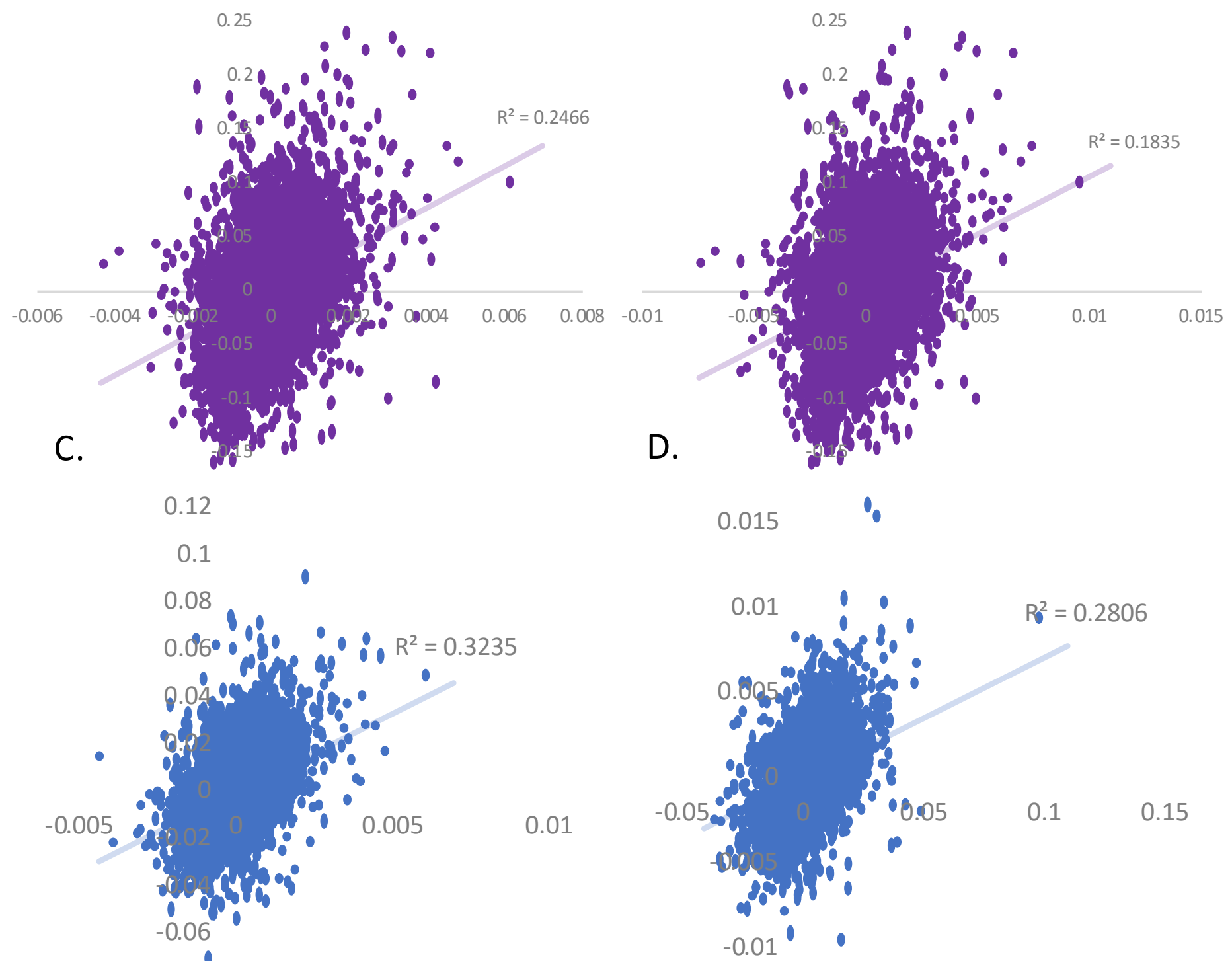

0.01

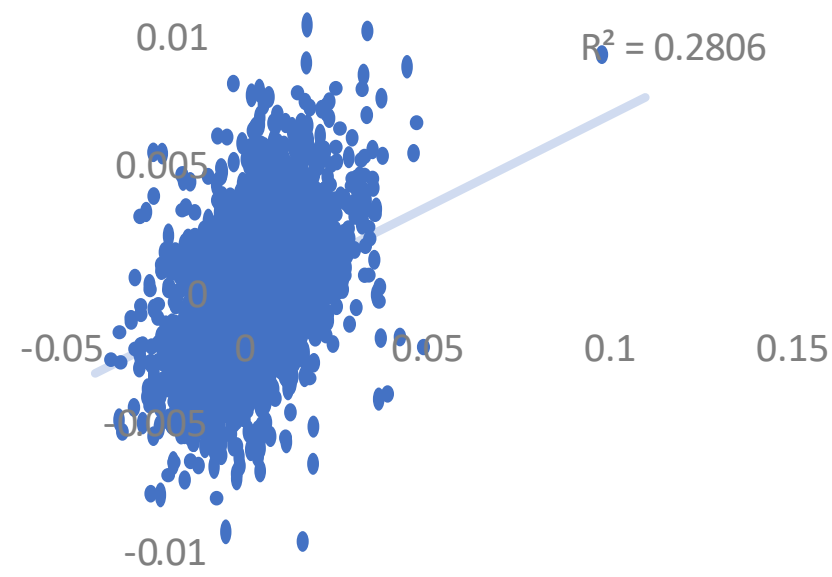

E.

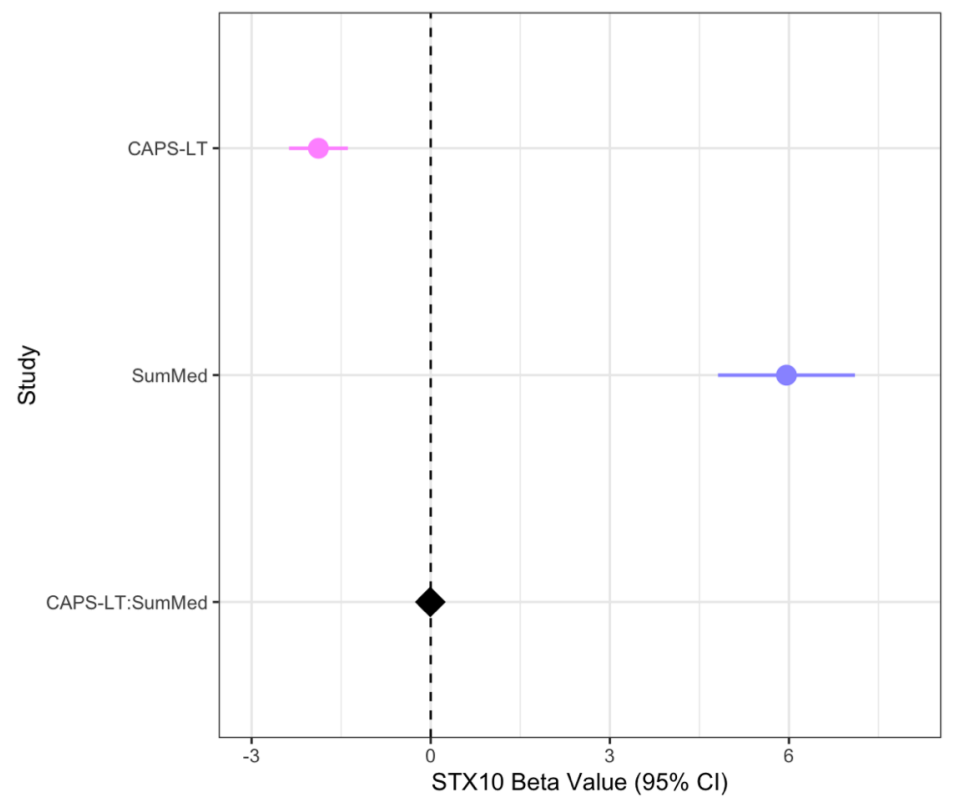


medRxiv preprint doi: https://doi.org/10.1101/2021.03.05.21252989; this version posted March 12, 2021. The copyright holder for this preprint (which was not certified by peer review) is the author/funder, who has granted medRxiv a license to display the preprint in perpetuity.

It is made available under a CC-BY-NC-ND 4.0 International license .

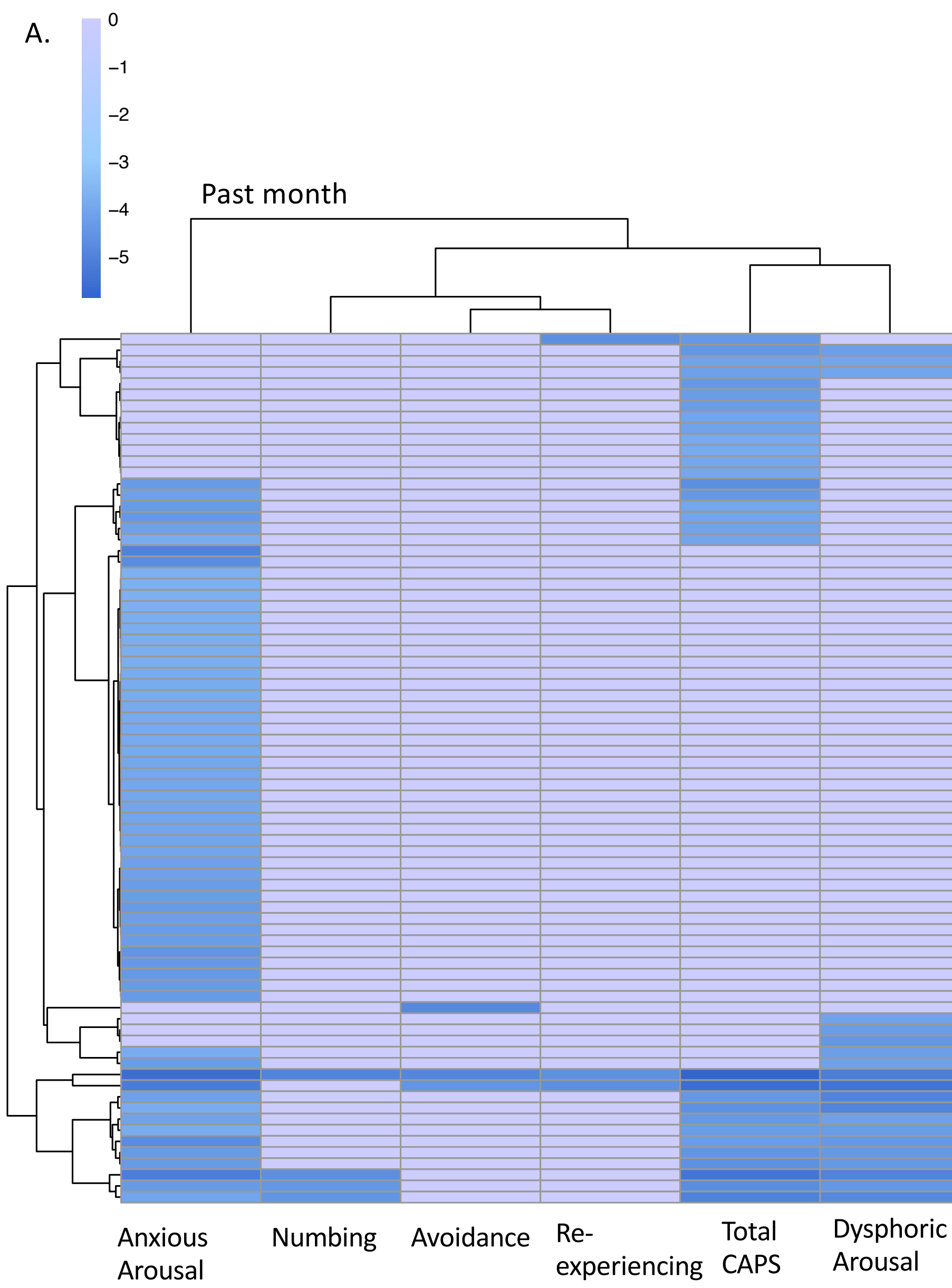

\section{Anxious experiencing CAPS Arousal}


medRxiv preprint doi: https://doi.org/10.1101/2021.03.05.21252989; this version posted March 12, 2021. The copyright holder for this preprint (which was not certified by peer review) is the author/funder, who has granted medRxiv a license to display the preprint in perpetuity. It is made available under a CC-BY-NC-ND 4.0 International license .

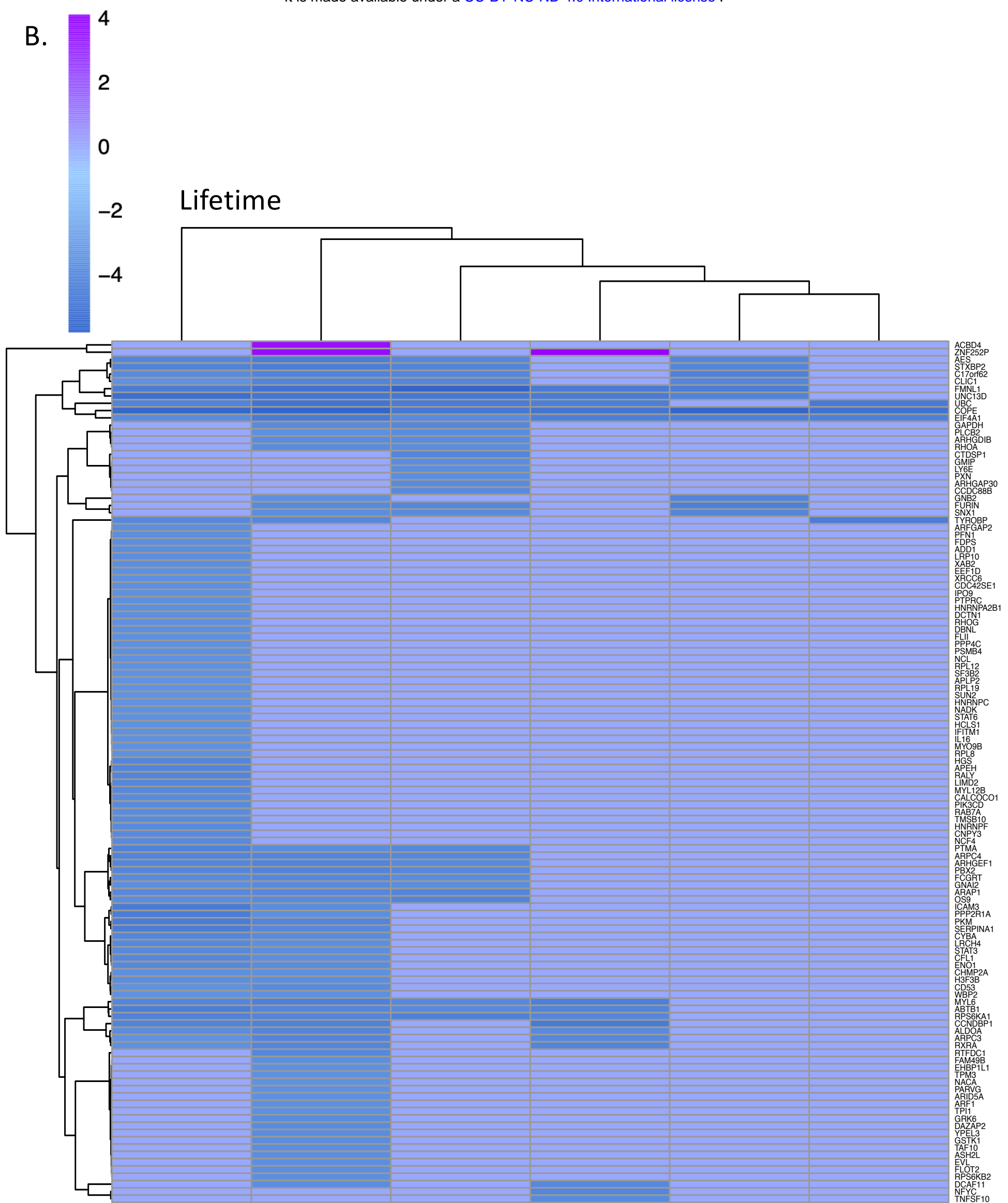

$\begin{array}{lllll}\text { Anxious } & \text { Total } & \text { Numbing } & \begin{array}{l}\text { Dysphoric Avoidance } \\ \text { Arousal }\end{array} & \begin{array}{l}\text { Re- } \\ \text { Arousal }\end{array} \\ \text { CAPS } & & \text { experiencing }\end{array}$


medRxiv preprint doi: https://doi.org/10.1101/2021.03.05.21252989; this version posted March 12, 2021. The copyright holder for this preprint (which was not certified by peer review) is the author/funder, who has granted medRxiv a license to display the preprint in perpetuity.

A.

It is made available under a CC-BY-NC-ND 4.0 International license .

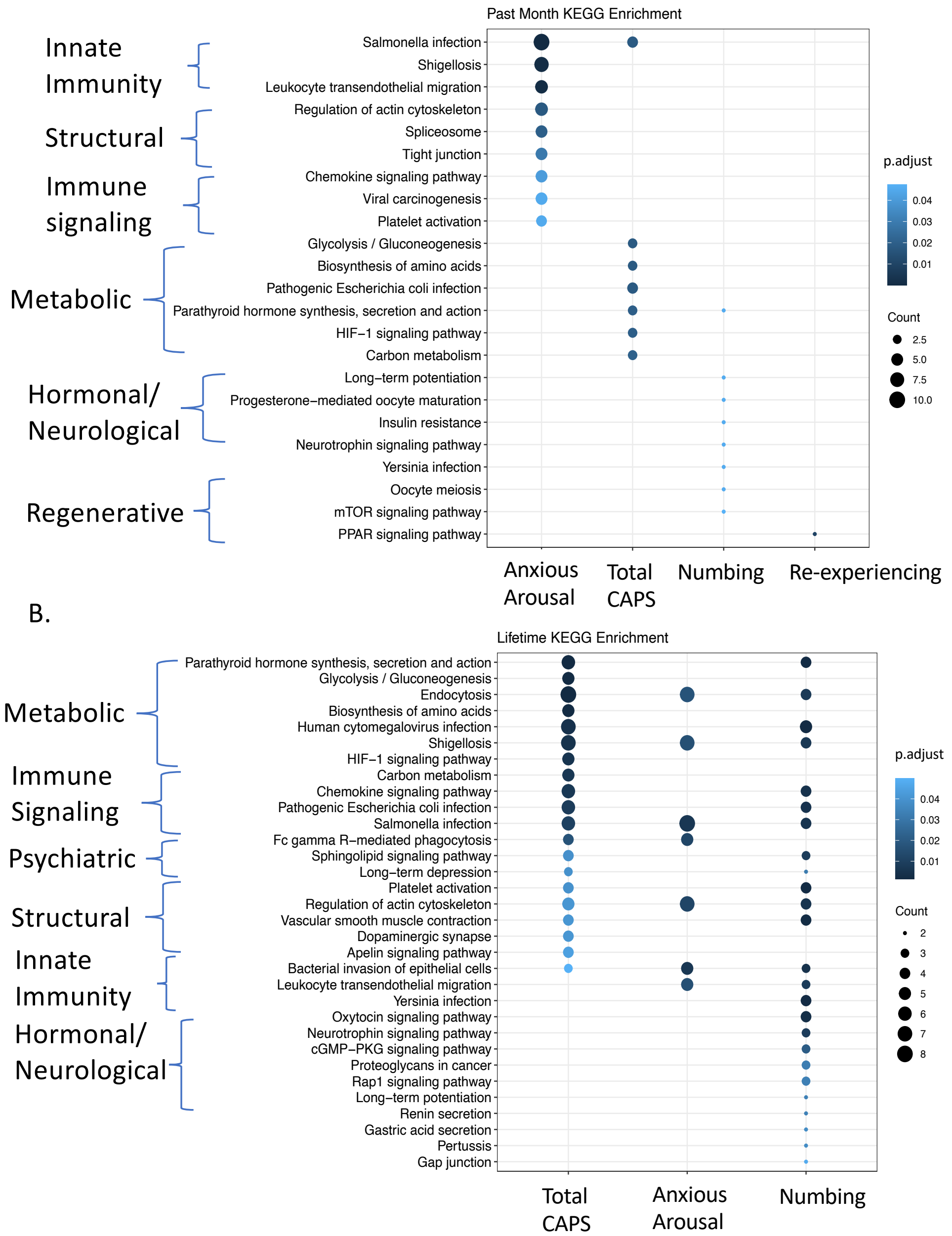


medRxiv preprint doi: https://doi.org/10.1101/2021.03.05.21252989; this version posted March 12, 2021. The copyright holder for this preprint (which was not certified by peer review) is the author/funder, who has granted medRxiv a license to display the preprint in perpetuity.

A.

C.
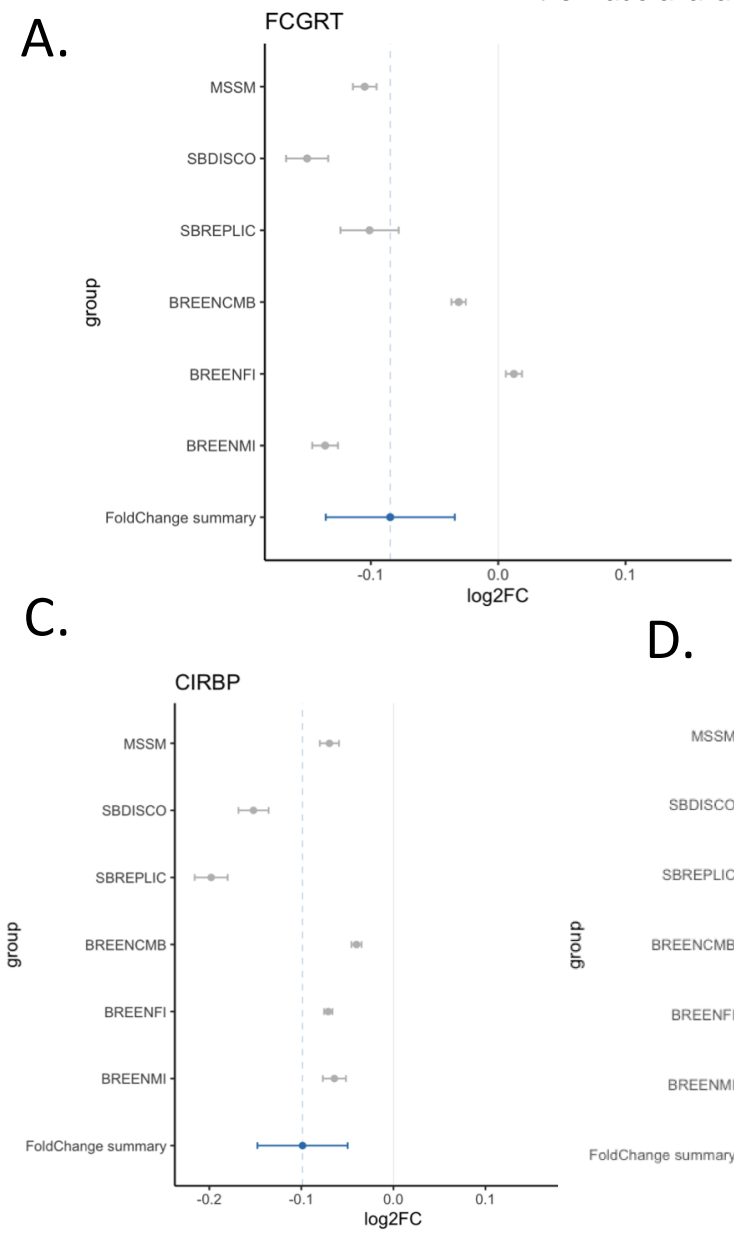

F.

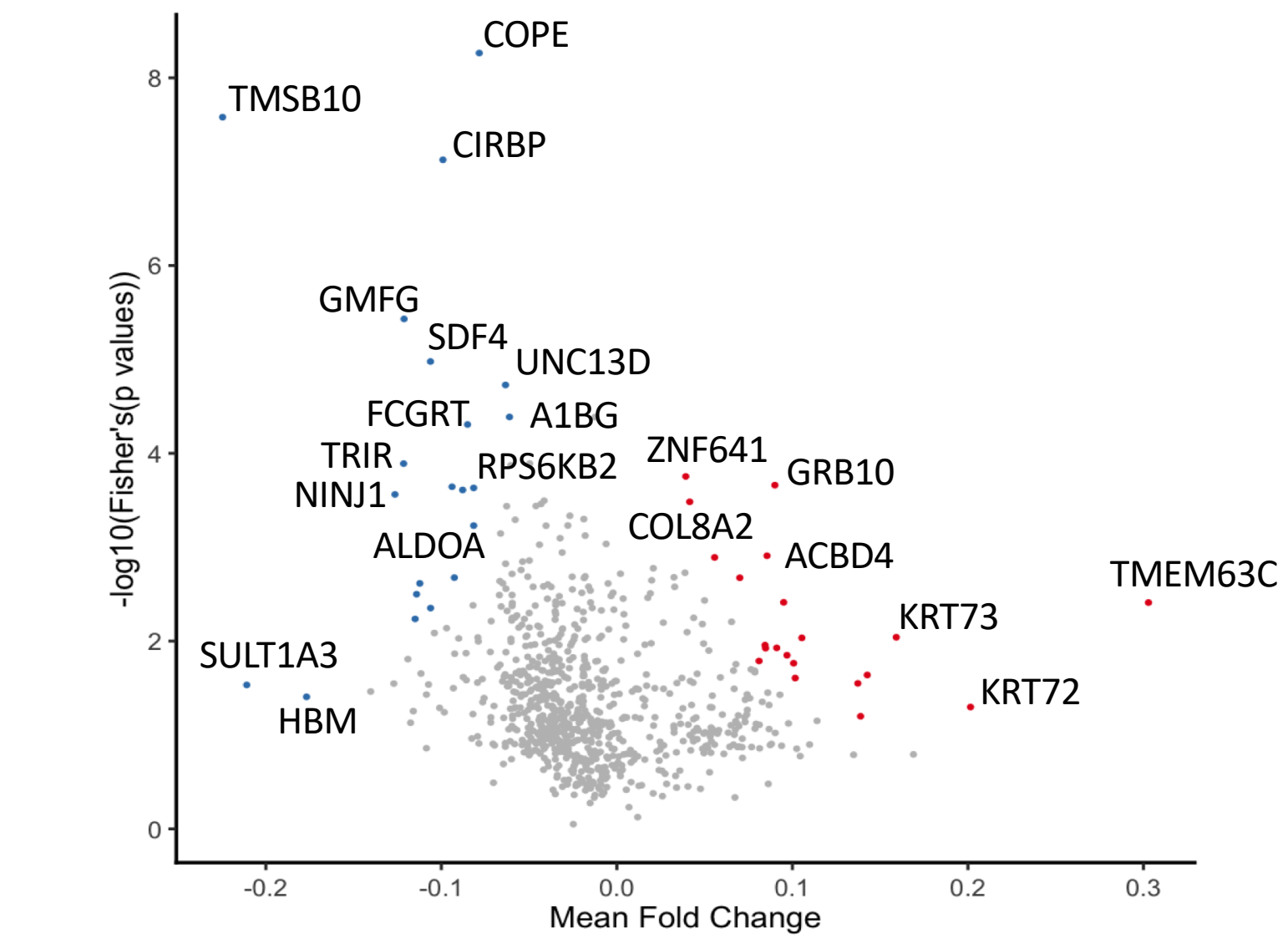

B.

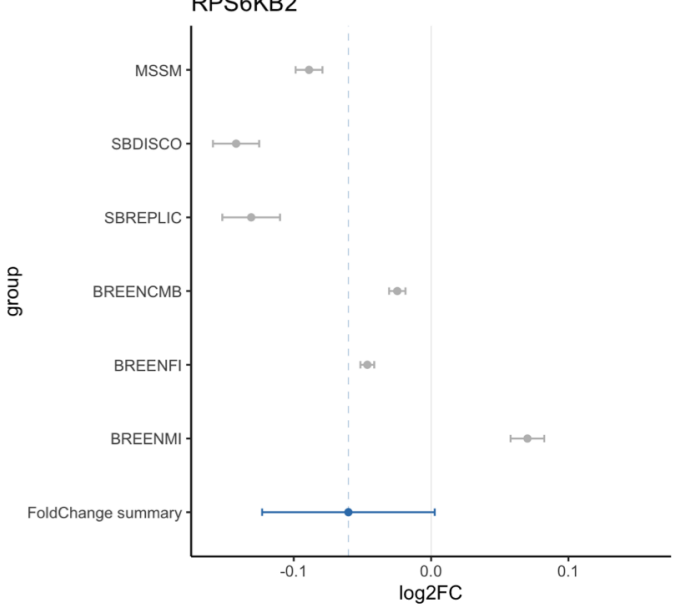

D.

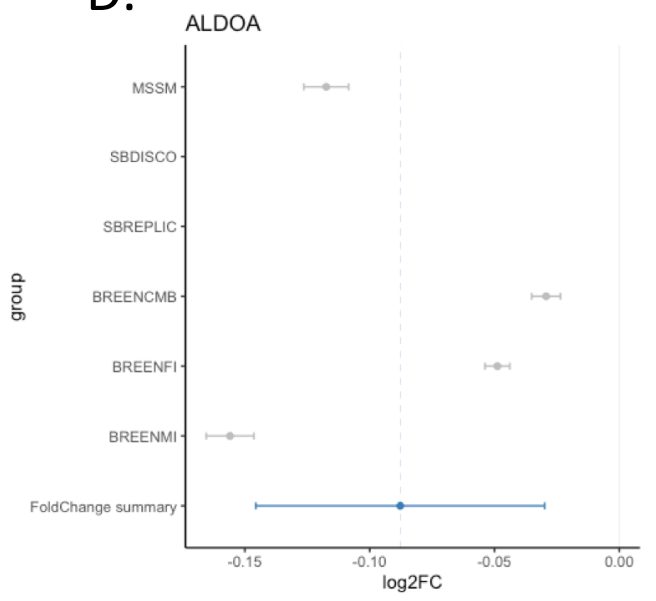

E.

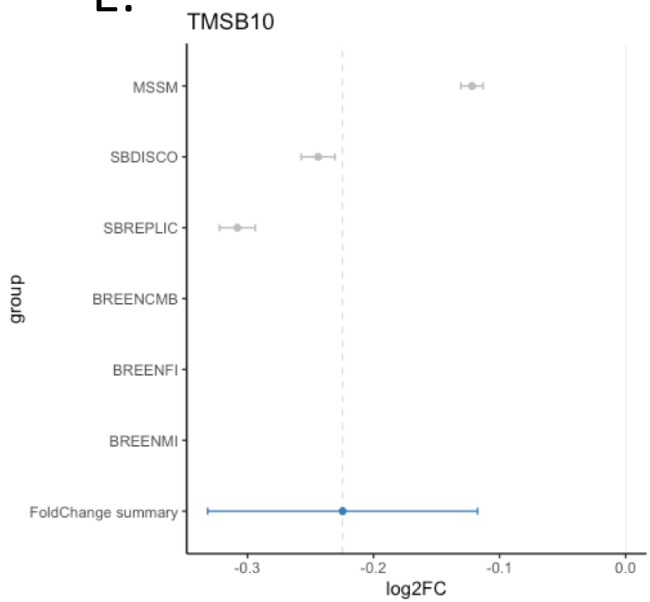


medRxiv preprint doi: https://doi.org/10.1101/2021.03.05.21252989; this version posted March 12, 2021. The copyright holder for this preprint (which was not certified by peer review) is the author/funder, who has granted medRxiv a license to display the preprint in perpetuity.

It is made available under a CC-BY-NC-ND 4.0 International license .

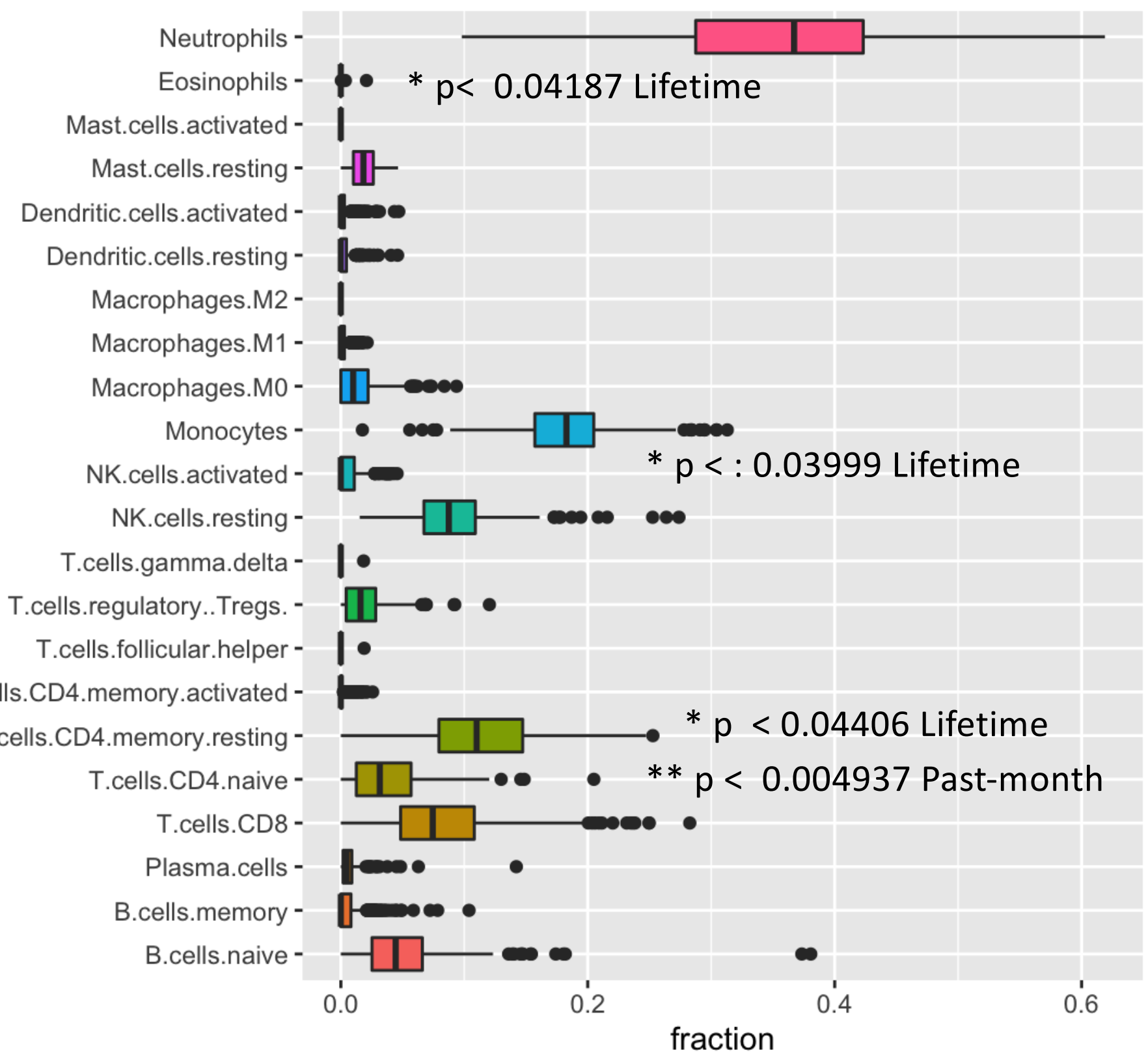

